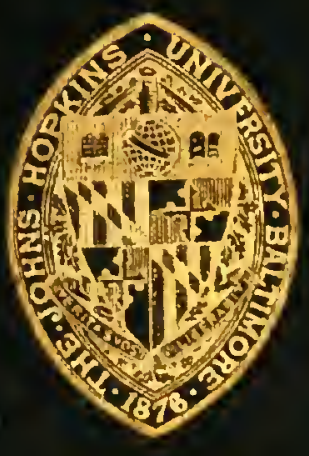




W. P. Itay,

Bifrgical sovity

Washington, D. $C$. 



\section{Etlemoirs from the Biological faboratorn}

OF THE

JOHNS HOPKINS UNIVERSITY

$11^{\top}, 5$

WIIIAM K. BROOKS. HDITOK

\section{OPHIURA BREVISPINA}

A DISSERTATION PKESENTED FOR THE DEGREE OF DOCTOR OF PHIJOSOHHY

TIE JOHNS HOPKINS UNIVERSITY

BY

\section{CASWELL GRAVE}

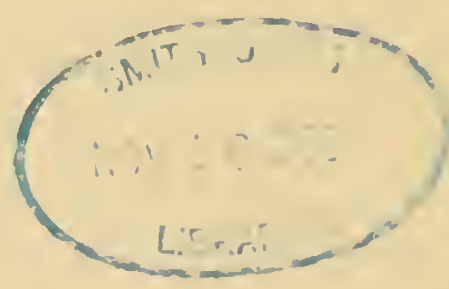

(Reprinted from the Memoirs of the National Academy of Sciences)

BALTIMORE

'THE JOHNS HOPKINS PRESS

1900 

As my name appears upon the title-page of this memoir, it is proper for me to state that my share in the work has been that of the instructor under whose direction the work has been done. The discovery that this Ophiuran is of peculiar interest and that it is unusually favorable for the study of the problems of the morphology of Echinoderms, was made by Dr. Grave; and the results which are here detailed are his work.

W. K. Brooks. 


\section{CONTENTS.}

l'age.

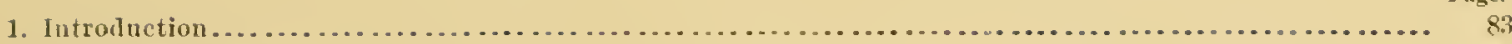

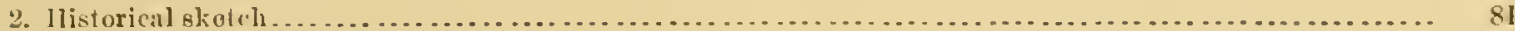

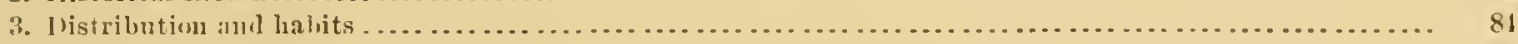

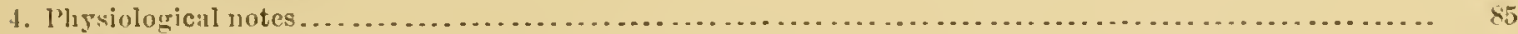

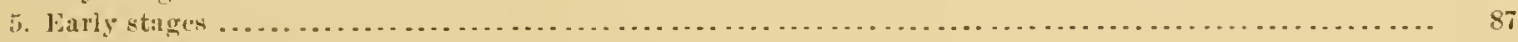

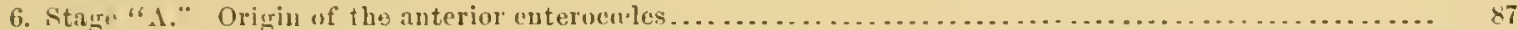

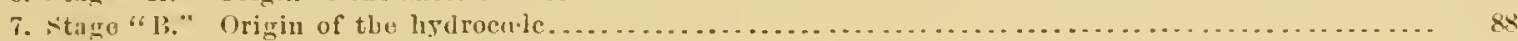

8. Stane "C," Closing of the blastopore and formation of the moutl ........................... 89

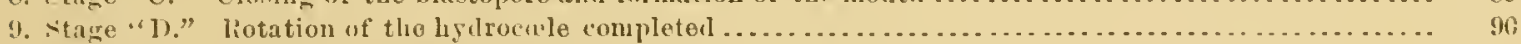

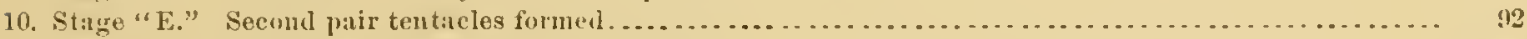

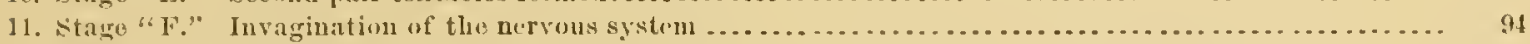

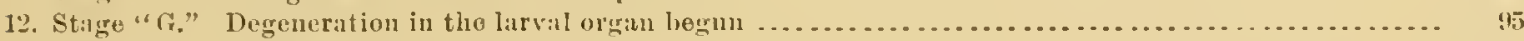

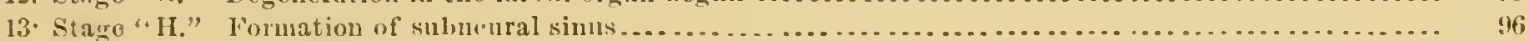

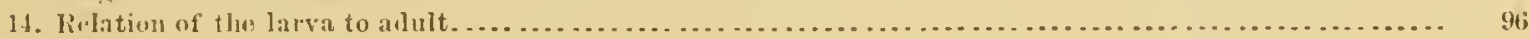

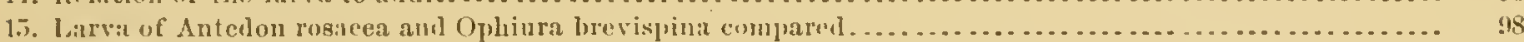

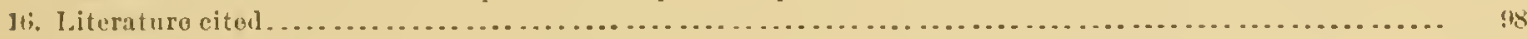

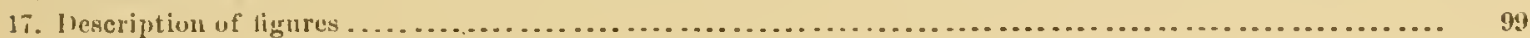





\title{
OPHIURA BREVISPINA.
}

\author{
By W. K. BRoOKs aml Casweli, Grate.
}

\section{INTRODUCTION.}

During the summer of 1898 it was my privilege to ocenpy the table of the Tolus Hopkins University in the I nitul States Fish Commission lahoritory at Woods Hole, and while here I reliscovered the peruliar (Ophiman hava. which was titst foum and figured by KromN (7).

Finding the larvit he destribed in the open sea knons dill not know to what spmies they belougel; but the lanva" the development of which is the subject of the greater part of this paper, came from eggs laid 11 annaria by (Jphiura brevispind. It is mot likely that the same sprevies of Ophiuran oceurs both at Funclial, where KRoMN dirl his work, aud also at North Falmoutl, where my material was obtained, but it is very probable that species belonging to the genus ophiura lave similar larval forms.

Among Eehinolerms, where a direct development from the larva to alnit ocimrs, thint is, witlont the usual highly specialized infermediate pelagic lava, we nsmally have to do with a speries which in some manner takes care of its brond; but in O. brevispina the larvit are free swimming, they being provided with a well developed loromotor apparatus, yet the usual (Ophiurial plutens larva is as completely omittul as it is from the lile history of the viviparous fmphinr squamela.

From the fact that the usmal plutens skeleton is begm in the larvil of o. brevispina one is led to suspect, howerer, that at some period in its history the species possessed a larra more nearly like a pluteus than at the present time. On the other hand, on aecont of the resemblanees which

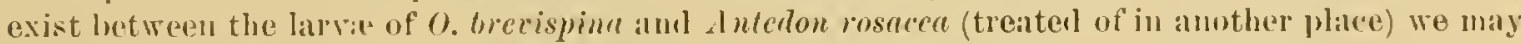
suppose a close phylogenetic relationship exists between then. If, as many roologists belicve, the erinoids have retained more narly than any other gromp the raracters of the primitive Echinolerm stock, then in the larva of O. brevispina we may have one which has retainel ummodified its primitive chinacteristies.

In this paper, however, the ficts only of levelopment are taken up, and the question of the bearing which this larva may have on any theoretieal disonssion concerning the interrelationships of the Echinoterms is suggested here in orler that the realer may lieep the subject before him while stulying the paper. The puints of resemblance between the Opliuran and Antedon larva are enumerated in a chilpter further ous.

The methou nsed in the prepiration of the material for micos(opieal study, and which gave good results, is as tollows: The lanil were taken up intu a pjpet with as little water as possible, and spnirter into a suall bottle contaimug a solution of sublimate-acetic (9S parts of a sat. sol. $\mathrm{HgCl}_{2}$ being usesl to 2 parts of glacial acetic acid). Alter fon two to live minutes the sublimate solution was drawn ofl gently, leaving the larva at tho bottom where they had settled. Then so per cent alcolul was added, which in a few minutes (.) was d lawn ofl and replacel by fo per cent alcohol, in which a little ioline hat been lissolven. In a few houl's (3-12) this was changel for elear 75 per cont alcohol, in whieh the larvin remained until needed lor babouatory stuly. Alter

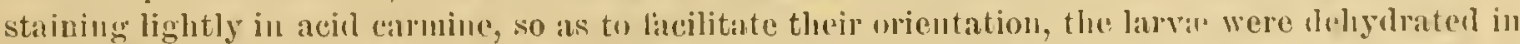
the usual way and cleared in oil of cloves. Fron: the elove oil they were uriented by a monlitaltion of the PATTON method. Alter an impregnation with $55^{\circ}$ paramin, series of sections three 
microns in thickness were made in three planes, transverse, longitudinal sagittal, and longitullnal horizontal. The sections were stained on the slicle with KLELNENBElig's hrematoxylon. Other methods were trien, but none proved so satisfictory as the one just deseribed. The shrinkage in echnodern tissue, which usmally accompranies the mumolitied paraffin method, was not to be seen in the tissne of these linvie, dne, no doubt, to its musual thickness.

It lias been thought hest to make the following list of terms which are used synonymonsly in the text of this paper in the description of the larvar. Those in the same line can, in most cases, be interchangeably nsed.

Dorsal-ahoral-above-over.

Ventral-oral-below-under.

Anterior-forwarl-before.

Posterior-back ward-belıiml.

In the drawings of the larvin, when the ventral side is up and the anterior end is nearest the top of the pagre, then the reader's left is also left in the figure.

For eonvenience in description, the various stages taken to illnstrate the life listory of the species have been designated by letters of the alpbabet, this methorl seming preferable to one in which age is used as a distinguishing character, since the progress of development at any age depends so intim.tely on the varying conditions of enviromment.

I take this opportunity to acknowledge my indebtedness to I)r. C. P. SiGEr Foos, at whose suggestion I began the stmly of Ophinran development.

I was aided very materially while at the Fisl Commission laboratory by l'rol. H. C. Bumpes, who placed at my disposal every facility for work at his command, and to him, also, I am greatly inclebter for many suggestions in methods of rearing larvar at the seashore.

To Professor Brooks, under whose direction my work has been done, are dne my warmest thanks for the interest with which he lias followed me in my studies and for the many raluable sngrgestions he has offered from time to time during the year.

\section{HISTORICAL SKETCH.}

The species of Ophiuran, Ophinu brerispina, the life history ol which is the sulpject of this dissertation, was first discoveren and described by Thomas say in 152. (12).

Since this time the species has becn rediseovered and renamed as many as three times. It is probably best known at present by nne of its synonyms. Ophiura olircece, which was given to it in 1865 by TIIEODORE LYMAN (8). In his earlier works LiMAN distinguished between f). olinueca and O. Urevispina, but in his Challenger report on the Ophiuride and Astrophytidle (a) lie places the two speeies together as one under its earlier name, which, althungh less deseriptive of the species tham that given by Lyman, it is probably best to retain.

In 1852 A I'Elis deseribed the species nuder the name Ophioderma oliraceum in Vol. IV of the I'roc. Bost. Soc. Nat. Hist.

LUtLEx also described it as Ophioderma serpens in 1850.

\section{DISTRIBUTION AND HABITS.}

Ophinre lrevispina is a very wilely distributed species, it having been reported linm points along the Atlantic roast from Brazil to New England.

It has been taken from the following localitics:

1. Bahia, lirazil.

2.. Port Antonio, Jamaica.

3. sit. Thomas, Bahamas.

4. Cape Florisla, Flurida.

5. Tortugas.
6. Beanfort, Nostl Carolina.

7. Old Point Comfort, Yiruinia.

s. Sag Ilarbor, New Iorli.

9. Hirtmonth, Massaclusetts.

10. New Bedford, Massachusetts.

11. North Falmouth, Massalelusetts.

That part of North Folmonth llarbor whind is inbabited by the species is very shallow, its depth at low tisle not excerling 1 liathon.

The bottom is covered with a mat of living and dead grasses anul alg:p, and in this tangle the ophiurans live, together with a great variety of crustacens, molusks, and worms. 
The usual cofor of the species is an olive green, with darker bauls an 1 lus arms amil sumetimes will a clombled disk.

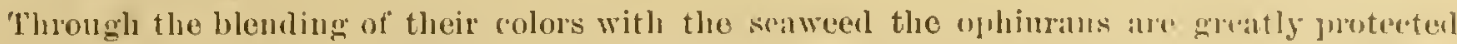
from their enemies, and it is difienlt, rven when looking for then, to see them anomg the seatreed so loug ats they llo not more.

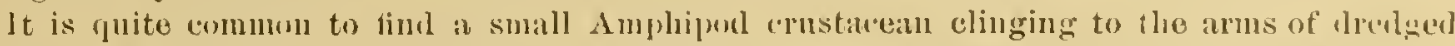
sperimens, and from the strueture of the crustarean it is probable that the two speries live together commensally. What benctit either animal atu derive from the association it is diflicult to see.

One pair at the thoracic legs of the crustacean is so moditien as to form a structure humbi. fully arapteil for chinging to the rouml ophinan arms. The last segment hut one of each of this pair of legs is $Y$-shaped. At the emel of one npm of the $Y$ is attached a movable segment, the end segment uf the leg, which when shut down npon the end of the other arm of the $Y$ incluses a triangular splace in which the ophiuran arm is held.

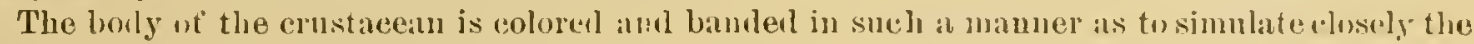
eolor ant banding of the ophimran arms.

When placel in aluaria with their host, the crustaceans cling to the ophiuran anms nutil the water becomes depleted of oxygen, when they leave the arms and swim alumt the alder of the alish apparently much alamed.

In examining the stomachs of the ophinrans one timls bits of other animals, such as erustanean appendiges and the skeletons of young hurseshoe crabs. From this it is probable thit the (reattures are senvenger's, since an aetive ermstaeean would harlly be captured by si) slow and ponly armed an animal ats an ophinran. None were ever observed to eat anything when kejet in the laburatory, and it is quite ont of the question to observe them in their natural lubitat, since they

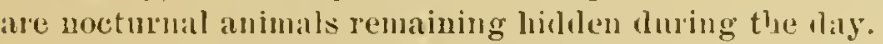

The oplinums were first eximined for sexual alements early in . Inne, and at that time the eggs were very large but allered closely together in the gonals. The sperm aljuarel to lu: lully formed but were nommotile.

From this time on until the middle of Angust the species was regularly watelud aml exim. ince, and on . July 16 the first ripe egus and sperm were obtained. A great number ut sperinens had that day been drelged and placed in ayuaria dishes ot tresh, filteren sea water. One week later a great mumber of alults were again brought in am placed unler the same comblitions as those which had spawned in the laboratory the week before, but this time very lew eags ware

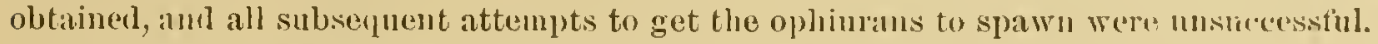

From this it would seem that the breeling seasum is extrenely short.

The time of day at which spawning occured copresponds well with the finc at which l have

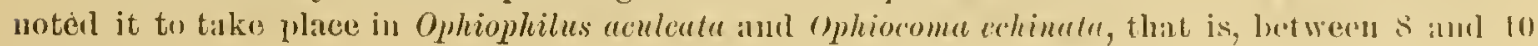
o'clock 1. In.

\section{PHYSIOLOGICAI, NOTES.}

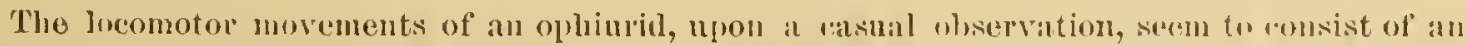
uncoorlinated writhing and twisting not ealendated to bring the creature tu foml or a place of safiety except by chance; hut a mole atreful stuly shows them to be the rusult of an orilerly and nicely coordinatul mexlianism.

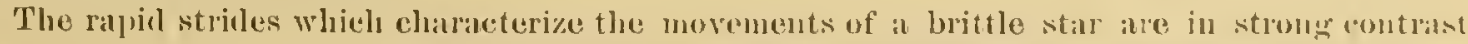

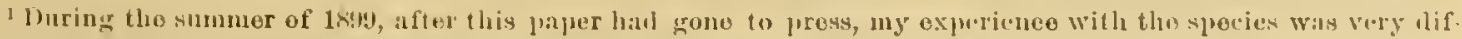

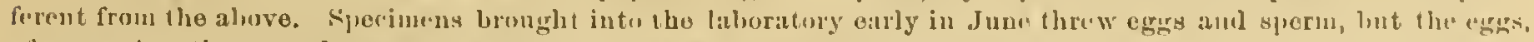

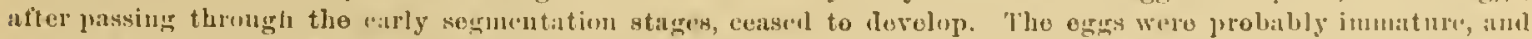

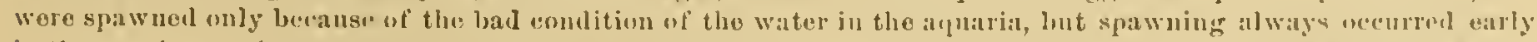

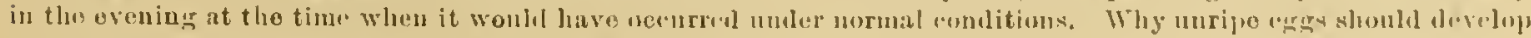
at all. or why egrs mature enough to begin their levelopment should nut be mature enongh to anulete it, is an intoresting "juestion.

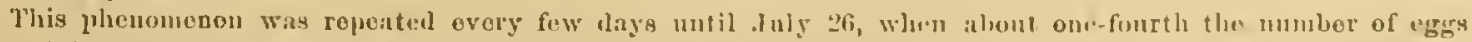

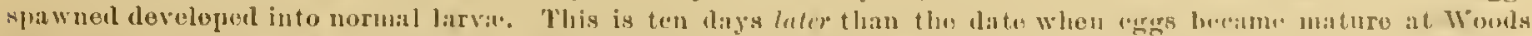

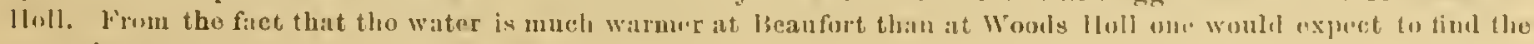
spawning soason oarlier at thu latter place.

10396 
with the slow ereeping movements of a startish or sea-urehin, the ditrerence being due to the employment of different locomotor mechanisms in the two cases; the startish and sea-urehiu depending entirely upon their tube feet and spines while in the ophinrids, the arms themselves are the eflicient locomotor organs, thry being nsed much as we use our arms in swimming.

'The arm of an ophiuricl consists of a large number of segments, each of which contains a central calcarious osicle. The calcarions ossicles of allacent segments articulate with each other like the vertebre of the spintil colnmu, and are joined together by tro pairs of museles in such a manner that motion is prossible in all directions. This meehanism is alded in producing the locomotion of the ereature not only by the arm sjines, where they are present, hut by the foot tentarles. These latter organs, which are the homologues of the tube feet of other erhinolerms, have been previously regarded as having given n] their locomotor function entirely, but I shall show further on that this is not true in the gemus Ophiura.

'The experiments I carried on last summer on the movenents of opliurans resulterl in little that is new, but on aconnt of the contirmation my notes and jhotographs give to Prerkes' work (11) on the same subject, it has been thought aclvisahle to jublish then.

In the usual method of progression one arm jrecedes, it taking no other part, apparently, than to joint ont the way; the two arms alljacent to and behind the anterior arm make the stroke; the remaining arms are dragged behind, aeting as a rudder.

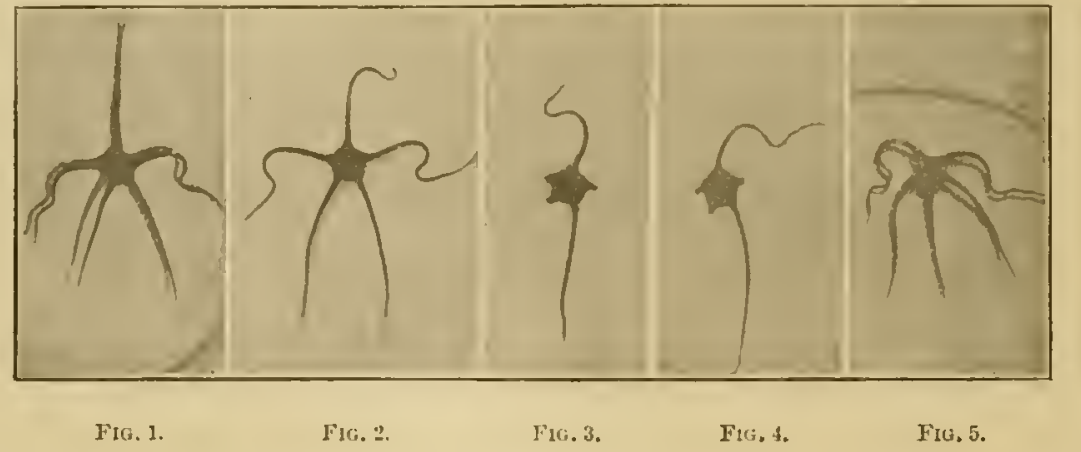

Xo preference as to which an shonld precerle could be found in an adult oplinuan, each arm being octulally capable of going belore, malking the stroke, or following behind.

If greater spreed is neceler, for example, to get away from a strong stimulus, the arm which precedes may also take part in the stroke, its coutractions being made simultanconsly with those of the side arms. This added force, if nerduced repeatedly on ono side, would soon rhamge the conrse of progression, but this difliculty is overome by an al teruation of the stroke of the preceling arm, first on one side, then on the of har (text tig. 2 ).

In a third method of normal locomotion the arms are arranged as is seen in text lig. $\overline{5}$, in which only one arm follows, acting as the rudder. This leaves two prairs of arms for the stroke, but the auterior pair is nsually most vigorous in its contractions.

Since $n$ physiolugieal differentiation into anterior, posterior, or lateral parts is to be found in ophiurids, the creatures are under no necessity of turning the body when a change in the direction of progression is to be made. The arm which finds itself pointing in the new dircetion to be traveled talies the lead, although it may have bern either lateral or posterior in position in the previous movements.

As has ben mentioned before, the foot tentacles atd in making the strokes of the arms eflicient in propelling the borly. After a strolie lats been made, whilo the ans are being lrawn forward ancl extenled for anew strolie, the tentacles can he seen moving actively abont, but as the arms come to rest for the baekward moviment the tentacles are thrust down agiainst the substratum and cease to more. The tentacles thins fit themselves into thro inequalities of the surface and alforl lixed points for the arms to pull ayainst. The tentacles of the posterior arms act in the same way, and are eflicient in preventing the torce of the stroke being lost in side motion.

In ophiurans with long arm spines these litter structures may perform the function just describen for the foot tentacles, but in the genus Ophiura the arm spines are very uninute and closely applicd to the sides of the arms. 
It is interesting to mote the wouderful condination of locomotor movements immediately following the amputation of three of the ams. In this ase if the nerve ring has been uninjured one of the remaining arms talies up the part of guiding and balanding. while the othel strokes tirst on one side then on the other (text ligss. 3 and 1).

When the rentral nervering is ent at any point the cordination in movement is imparen, and when cut in fivo places, between the arms, it is lost antirely.

When placel on its aboral surface an ophinan gujekly turms over. The methor nsed is quite definite; two adjiacent ams straighten out so that together they form a straight line. On these arms as an axis the body revolves, being pushed orey by the three remaining arms, but mostly by the melian one of the thee.

EARLY STAGES.

The mature egos are opayne and vary in color l'mom an olive green to an orange yellow. Those of the sime individual, however, are eonstant in their coloration. Until quite well developel the larva jetain the color which was on the egres at the time they were laid.

For echuoderms the aggs are very large, being 0.3 millimeter in diameter.

Soon after they are fertilizul the eags throw off two memblanes, the first of which is much thicker thin the secoml.

When first lail aml luring their early derelopment the rags tloat, but when their eilia are formed the larvir are able to swim below the surtice.

As I dil not know that any special interest would ho fomnd in the life history of the species, I dicl not callefully observe the early stages while living, nor preserve material for future study, and as I lave statel elsewhere, all later attempts to get uther material were musucessful.

This makes it mecessary to begin this paper with the description of a late gastrula in whieh the first pair of enterocues have ahealy begun to form as lateral ponches from the anterior free end of the archenturon (figs. 1-i3).

Larvin in this stage of" development will be llesignaterl as "A."

$$
\text { STALE "A," } 36 \text { HOURS UL1". }
$$

(Finures 1, 2, amd 3.)

At the age of 36 homs the larva swim actively, they being nuformly covered with eilia (lig. 1).

The shape of the larva is an oval, the length being to the shorter diameter as "2 is to 1.

The amimal or anterior pole is slightly mole pointel than the posterior vegetative one. The ventral sulfice is listingnisher by the presence of the blastopore, which batter has been pushed from its posterior position to a rentral one by the rapial growth of the ectoderm of the alorsal surface of the darva.

An apieal plate of taller cells is present at the anterior emol, lout I couhl not see that the cilia at this puint were any hoger than those which (over the other parts of the larval (tig. $:$ ap).

From the blastopore, throngh which its eavity opens to the exterior, a large archenteron projects lorward into the blastocuale.

The remaiuler of the blastoure, not taken uphy the archenteron or its punches, is tilled with a close network of mesenchyme cells. This mesenclyome isisuc is shown in tim. 3, mes, which is a lougituliual sagittal section of " $\mathrm{\Lambda}$."

From the anterior free end of the archenteron a large ponch is in process of being eut ont. This ponch projects to the right and lelt as horn-like processes, which lat ter are to be considereal the rudiments of the right and leit anterior enteroulos (fig. 22, aer and acl).

As to the methoul of gastrulation I can mot at present speak from observation on larval in which it is just taking plice, but trom a study ol the stawe now under enusileratiun some idea can be gotten as to how it has promeded. In figs. 1 and 3 we see a cellular plug (col) juntruding from

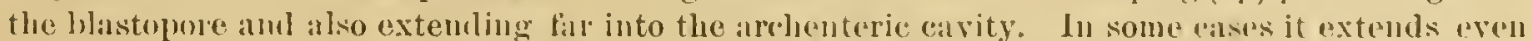

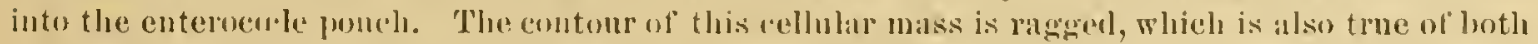

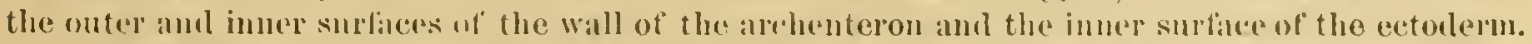

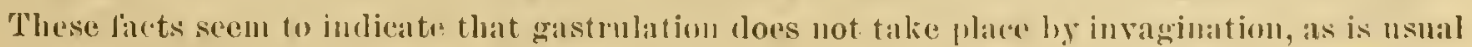
in echinoderms, but that the larva betore gastrulation is a solid, planula-like afrair, and later the 
archenteron is formed by a splitting aw wy of the central eore. In the same way the plug of eells is probably formed by the liollowing ont of the solid archenteron.

Beside their ragged ontline the walls of the barra have another peculinity in their structure, for, julging by the number and pesition of the mnclei, they are from two to three cells in thickness (tim. 3).

Cell walls are not distingnislable in any stage of divelojment.

Stalie "B," $\$ 2$ HIOLRS OLh.

(Fignres 4 and 5 .)

Aceording to Burr (2) the hydroenle does not have the same origin in all the groups of eehinoderms. Ile found that it originates in the crinoids, sea-urehins, and starfishes from the left anterim enterocule, but in the ophiurids it grows out from the anterior end of the left posterior enterocirse.

This olsservation, which Bury reeords with apparent hesitation, I can completely confirm, as will be seen in the deseription and fignes of "13."

Externally the appearance is the same as in "A," bnt the intermal structures have undergone a great ehange.

The anterior pouches, the cavities of which in "A" were connected both with each other and with the ravity of the arehenteron, are now separate and distinct. The conneetion betreen these structures still continues, lowever, in their fused walls. The lett ponch is a little larger than the right and lies belind and to the left of the latter (fig. 4 , ael).

Just below the anterior ponelies there is to be fonml a third ponch, whieh is groming ont from the left side and anturior end of the archenteron (fig. 4, hy). It protrules anteriorly and partially eovers the $t m o$ anterior enterocriles. The cavity of this ponch, which is the rudiment of the hydrocule, is in wille communication with the arehenteron.

From the wall forming the convex sindes of' the hydrocule there are, even at this early stage in its formation, five ontgrowths which are the beginnings of the radial canals of the adult ophiuran (fig. 4. 1, 2, 3, 4, aml i).

The whole hydrocale is curving round to the right to eneirele the asoplhagus, which latter is making its first appearance in this stage as a shallow but definite pit in the central part of the ventral ectodes'mal wall (fim. $t, 0 \mathrm{e})$.

To aroid confusion the lyylrocrle was spoken of above as arising from the archenteron, but, as will be seen in the transverse seetion (fig. 5), taken in al plane prosterion to the origin of the hydrocole, a ditlerentiation is talingr plare in the archenteron which enables us to distinguish in it the rudiments of two structures, the posterior enterocreles and the stomach. Fy a longitudinal eirenlar furrow the archenteron is being ent horizontally into a large ventral pound, the posterior enterocoles (pe) and a sululler dorsal one, the stomach (s). This stomach rudinent bends aronnd the posterior end of the posterior enterocule and opens to the exterior through the blastopore (fig. 4).

It is from the left side and anterior end of the ventral poneh that the lyydrociele grows ont, leme the confirmation of Bunr's statement that it arises from the left posterior enterocole in ophiurids.

lu most echinoderms the posterior enteraceles originate as paired structures, and if the statements of BURY and MClBRIDis are eorrect, that the left posterior enterockele of the larva forms the liypogistric bolly eavity of the adhlt, and the right posterior enteroen.le goes to form the prigastric colom, then, aceorlmg to this. the lan'we ventral poneh, whieh I regard as tho finsed right and left posterion enteror'ules, really represents the left only, because it takes no prart in the formation of the epigastric body cavity of the alult oplinurid, but, with the Jeft, does pass directly into the hyogastric.

The origin of the epigastrib enteroule is discusserl in the description of stane " 0 ," in which its ruliment is first found over the stonach.

My reason for regarding the ventral ponch of " $\mathrm{B}$ " as the finserl right and left posterior entero. "rues, is that at the time of its origin it is symmetrieally disposed on either side of the plane of larval bilateral symmetry. 


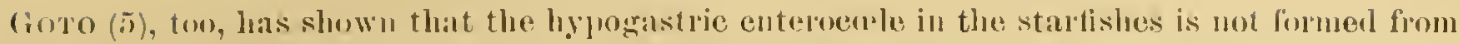

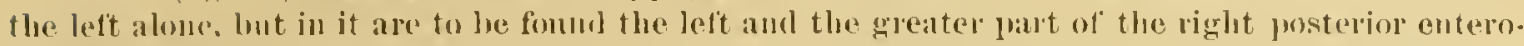
colles.

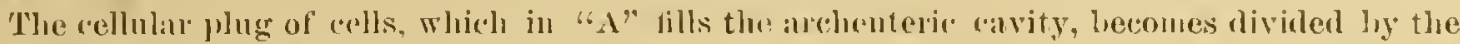

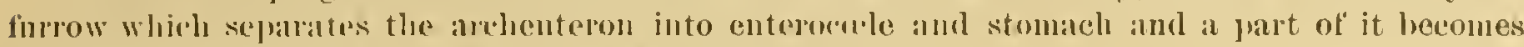

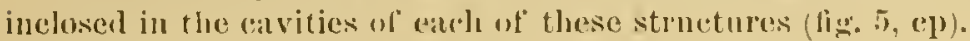

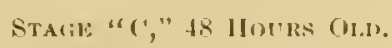

(l'igures 6,7, and 8. )

The external form of the larva, which in this sories of embryos is six homrs oleler than "B,"

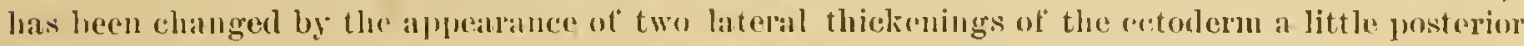
to the median transierse plane (fig. 6).

The blastopore, which in "1;" was open to the exterior, has elosed, leaving no trace of its former position.

The mouth and asophagus, which existed in " 13 " only as a shallow ectoderual pit, now have the furm of a cleep, hollow tube (tigs. 6 and 7 , m and oe), which projeets vertically inward until it passes through the hydrockle and beyond the posterior enterocale, when it curves biek under the latter to fuse with the anterior wall of the stomaeh.

The stomach and posterior enterockle are still in open communication, as in "l," but the firrow in "C" has deeprned, and the process by which the two structures are being separatris almost complete (tig. T).

Althongh the walls of the asophagus and stomach are fitsed, their eavities are still separate.

This condition render's it casy to see just what part is played by the ectorlerm in the formation of the alimentary canal, the entire a'sophageal eavity being surnounded by ectoderm.

ln "B" the hydroeale communicites with the posterior enterocole lyy a wisle ojrening, and at the same point in "C" the two struetures are still in communication, but the commetion has been nariowed down to a small tulse (fig. 7 , lı: ).

Beside this connection with the posterior enterocole, a second tube has heen formed, joining the left anterior enteroenle with the hydrocme (fig. 7 , st). This new tube, which is the rudiment of the stone eanal, enters the liydrocne at the same point with the tube connecting the latter with the posterior enterocirle.

The left anterior enterockle lies to the lelt of the asophagus, and dorsal to the left half of the hyrlocrele (tigs. 6 and 7 , ael).

It is to be noted that, although we now have a larva jossessing both hydrocole and stone

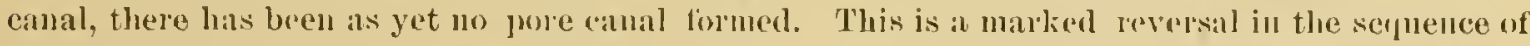
the formation of these structures from what might be expected from the order of theil appeananee

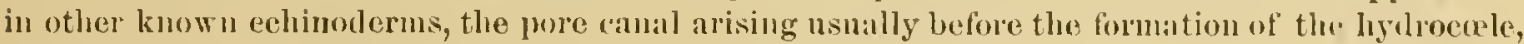
while the stone canal appear's melı later than either.

lieturuing to the hydrocule, we thid it a horseshoe-shaped stincture astide the arsophagus (ligs. 6 and $\tau, h y$ ). The bulgring areas which are to torm the radial canals of the adult are much long̈el and nore legular in size than in "I?," The radial joureh, which lies to the light of the a'sophagis and at the end of the right horn of the horseshoe, will herealter be spuken ol" as radial canal 1 , since it arises from that part of the hydroenele which was first to bud ont fom the

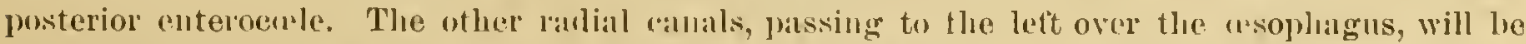
designater as "2, 3,4 , and $\tilde{\pi}$. Radial canal 5 lies in this stage over tho opening of the stone canal.

The rotation of the lydroende anound the "sophagns from its original left position, which was hegun in "l,", has continuel to such an extent in "U" that hall" of it lies to the rierlit of the median sagittal plane of the laval and land to the lett. Rarlial anal a lies in this plane and [roints dirent] townd the anterior end of the Iarva (fig. (i).

With its rutation the lydrocule also moves borlily towad the posterior end of the larvis,

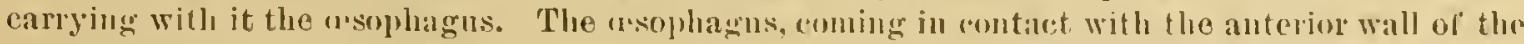

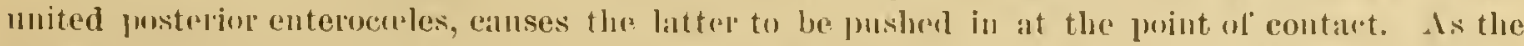

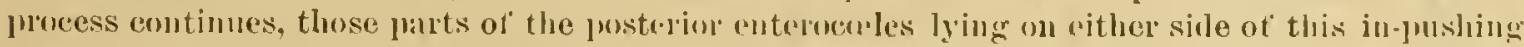
area are forced to How forward around the asophlag gus and mudep the hydrocule; this we have 
the posterior enterocirles becoming borseshoe shaped, the two horus of which lie under the horns of the hydrocule (tigs. 6 and $i$, he and hy).

Lying dorsal to the stomach we find a small enteroeke which was not present in "B," or if present, not in this position. It is the rudiment of the hody cavity, which in the arlult lies aboral to the stomach am which has been recently appropriately termed the epigastric enterocele (figs. (6) and $\tau$, ee).

As to the origin of this structnre I have no direct observations to give, but certain facts have led me to believe that it is formed firom the right anterior enterocele. These facts may be summed up as follows: 1 " " $\mathrm{B}$ " no epigastrie enterocule exists, but the two anterior enterocr.les (lig. 4 , aer and ael) lie side by side anterior to the stomach and the posterior enterocrles. In "C" (figs. ( $j$ and 7 , ee) an epigastric pouch, equal in size to the right anterior enterocule of " $B$ " is to be fisum, but by the side of the wophagns only the left anterior enterocole remains (figs. 6 and 7 , ael).

Dnring the six hours which intervene betreen " $B$ " and "C" it seems hardly prossible that a complete formation of the epigastric enterocrele should have taken place or that there should have been time for the complete degeneration and disaplearance of the right anterior ponch; sufficient time may liar "lapsed, however, for the migration of the right anterior entervecte to a position behind the stomach.

A gainst such an interpretation as the above there is the faet that in no other ease has the "pigastric enteroerele been olserved to take its origin frum the right anterior ponch. It has been describer as arising from the right postrior enteroente, lunever, as has been referred to before, in all the gronss ly borr, and his obsenvations have bren corroborated by both MICBRInE and (iоTo in the startishes.

STAGE "D," 60 IULI:S (I,.

(1)igures !-11.)

The changes which have taken place in "C" to produce " $\mathrm{D}$ " are very marked.

The eilia have disalpreared, except in four transverse rings or bands, three of which extend entirely arome the lody of the larva. The third ring, connting from the anterior end, is interrupted by the aboral disk on the rentral surface.

This third eiliated ring first appear's on the lateral bulges, which were deseribed in "C," and the fonrth ring appears on a second pair of lateral bulges which originate behind the first pair near the josterior end of the larva.

The shape of the larva is no longer oral, but the posterior end has widened laterally ancl become somerhat dorso ventrally compressed (fig. !). The anterior end has not changed in shape and may be thonght of as forming the handle of the now elub-shaped larva.

The enlarged posterior ent of the larva contains anl its organs and is the part whith will enter directly into the formation of the adnlt ophiurisl.

From its lomology with the prenral lobe and larral organ of Asterinu gibbose I have called the anterior end of the larva the larval organ. It disappears with the metamorphosis into the ardult form.

The larral organ is also homologons with the stalk of the Antulon lirra, although in the ophiurid larva it never functions as an attachment organ. When swimming, the larval organ precedes. It is tilled with a network of mesentehyme cells (igg. 11, mes).

luternally the changes have heen even greater than the external ones we have just (onsidered, for it is during this perind of derelopment that the rutation and reacljustment of organs takes place, which is present in all echinoderms at some stage of their development.

The hychrorele, whieh has begnn its rotation about the esophagus as an axis in "C," has (ompleted it in "1)" and reached its definite prosition.

That part of the hydrocule which in "C" was sitnated on the left of the plane dividing the larva into bilaterally symmetrical lablves, now lies on the right side of the same plane and vice versa. (Compure ligs. $(i$ and 9.$)$

A revolution of $180^{\circ}$ hats taken place in the hydrncerle since "C," to which if the 1801 ) of rotation be added, which took place up to the time of "C," we have a total rotation of 360 ' in the 


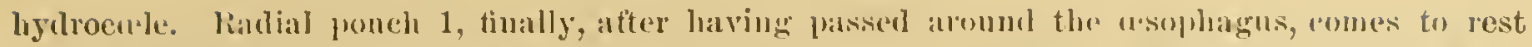

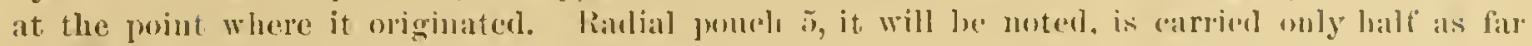
as ralial jouch 1 , or fiom its point of origin on the left to a point upposite wh the right of the usophatgus. (Complate tigs. li aml !), (1) and (.j).)

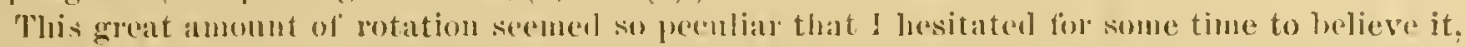

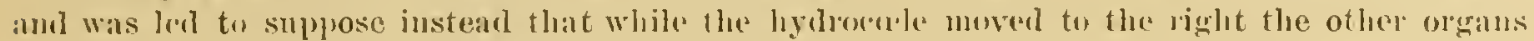
lyiug above it rotated an equal amount to the left.

The early elosmre of the blastopore and the central prosition of the mouth in the "arly stages make such a view as the latter seem possible, and as it may suguest itsulf to those who study figs. 6 and 7,1 will grive below the points which secm to me, directly ar indirety, to prove that the hyllowe revolves under the enterocules and stomach, lathel than that the latter twist over the hỵirucirle:

(i) The actolemal bulges, nearre the posterior end in "C" (tig. 6), are tho same as those

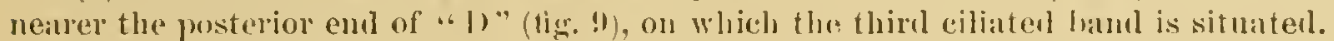

(b) If the latter viow is the comect our then lialial canal 3 prints toward the same end of

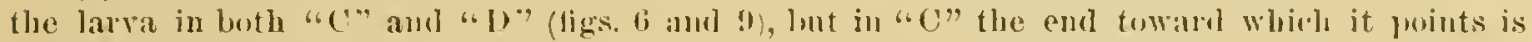
anteriorly" direeted in swimming and in "1)" it puints awa fiom the end which preceles. It is hardly thinkable that in any stage in its development the anterior end of a larva should vhinge its plysiological function and herome the justrior end.

(c) By any other view than the one I have alopted the blastopore, or the joint where it existed before closing, would be anterior and the larval organ postrom in position. In all kuowi echinolern larva, however, the blastupole marks the posterior emb, and in all ases where it oecols the larval organ originates frou the anteriol emb of the larvir.

(d) It may be recalled, also, that in the realjustment of parts which takes place during the

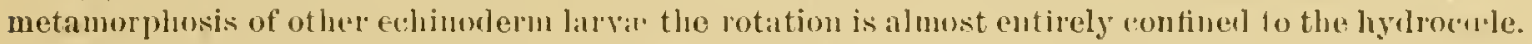

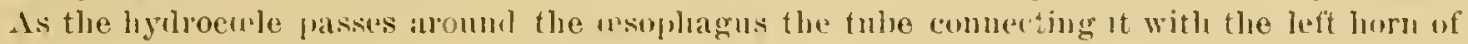
the hypogastric enterocold lwames broken and the left anterior anterocule, together with the tube connecting it with the left hom of the hydrowale, are cirrien anteriorly aromil the nasophasus

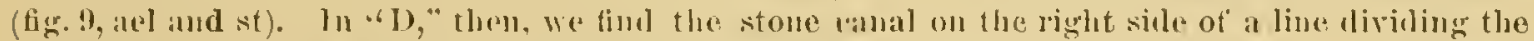
larva into symmetrical loatves, insteal of to the loft of the same line as it is in "C." (Cumpare figs. (i and 7 with 9.) The anterior conterorele comes to rest immediately in front of the stomanll aud [usoplliagus.

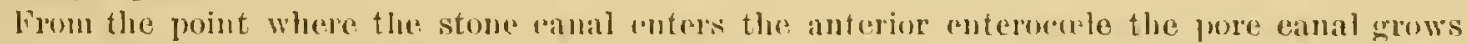
out, fasses dor'sally to the ectokerm, with which lafter its walls finse, and all ofrening the water

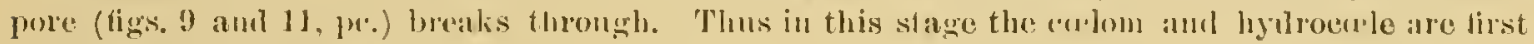
connected witl the exterior.

In "C" the circular watereanal hat not closid, but existed in the form of a horseshom, the

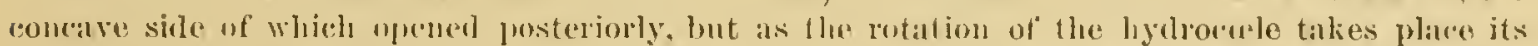

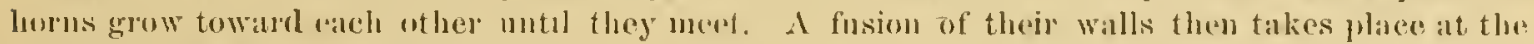
peint of eontact and a complefe ring is thus formenl. The part of the ring caunal. the formation of

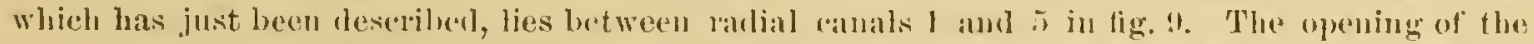

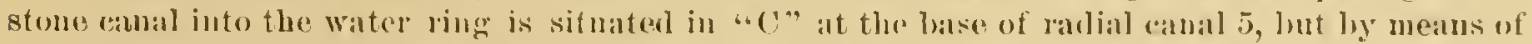

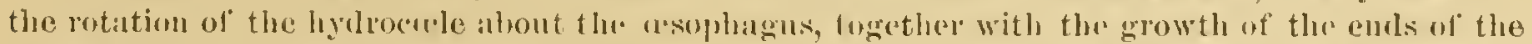
horseshor, this opening is earricl away foun its position at the base of radial canal 5 foward radial camal 1. It always remains, hwever, nearer the former than the latter: in other words, jt

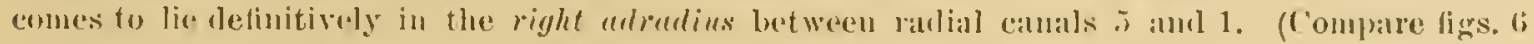
and 9.)

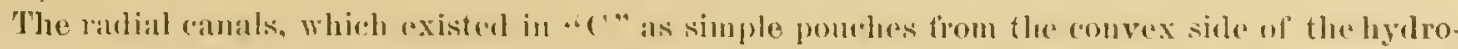

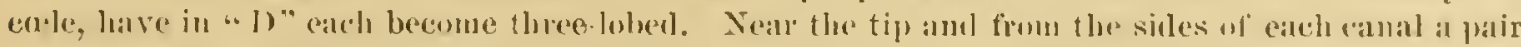

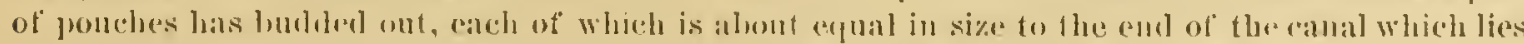
between and hejoud them (fig. 9, et and ti). In these thleestructures we have the pudiments of the end tentable and the lirst pair of fout tentales of the ophindirl allu.

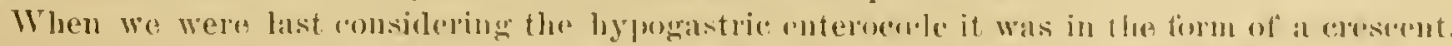
the horns of which were very shont and its central jant very wirle. luto its concarity, which was 
anteriorly directed, the asophagus fitted. The horns of this enterocole, beginning in "C" to grow over the hydrocile, continue the [mocess during the rotation of the latter, the borns of the crescent growing at the expense of the thickness of its central part, ald in "D" we have this enterocuele lying directly over the hydrocurle in the form of a perfect horseshoe (tig. 9, he).

Between the ends of the horns of the liypogastric crilom lies the anterior enterociele. The walls of these structures come together and finse in such a way that they together form a hollow cirrular colom surrounding the stomach and lying over the somewhat smaller water vasenlar ring (fig. 9).

In the four interradii, marked by their positions between radial canals 1 and 2,2 and 3,3 and 4 , and 4 anci $\bar{i}$, four jonches of the hypogastric enterocule grow downart, outsile the walter vascular ring, forcing themselves between the radial canals; a fifth ponch, similan to those just deseribed, is formed from the lett anterior enterocerle in the remaining interralins between radial

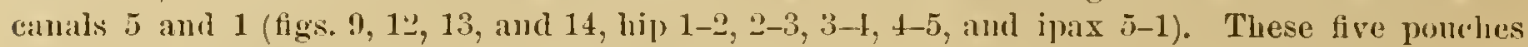
are the rudinents of the onter lerihamal ring, which will be more fully considered in the succeeding stages.

The stomach, after being entirely cut oft' from the hypogastric enterocule, was drawn forward during the rotation of the hydrocere, and the cropliagus was carried in the opposite direction, so that in "1)" the stomach lies almost directly over the "sophagus (figs. $S$ and 1:3, ve and s). The partition, which in "C" separated the cavities of these two structures, has disappeared in "1)," and the crsophageal cuvity opens into that of the stomach. There is present, then, in "D" the definitive alimentary canal of the adult ophimid.

The "celhular mass," which in " $\mathrm{B}$ " and "C" was being dividerl into two parts by the constriction separating the arehenteron into enterncule: and stomach, is to be foumd, in sections of "I)," in the (ravities of" both the above structures (figs. 11, 12, 13, and 14 ep).

Lying immediately above, or aboral to, the stomach is to be fond the epigastric enterocule. It has cnlarged consider"ably dnring the inlerval between " $\mathrm{C}$ " and " $\mathrm{D}$, but is not yet of sufficicnt size for its walls to tonch those of the hypoganstrie corlom, and bence in this stage no cirrular aloral mesentery is to be fimull.

STatil: "l\%," 60 Houks OLl.

(r'igures 15-21.)

The thickening of the ventral ectoderm which was hegun in "1)" has contimed during the six hours which intervene between "1)" and "E" and has spread to the sides of the larva (figs. 15 and 19-21).

Near the edge of this thickened oral disk are to be fomml tive groups of romude elevations of the ectoderm (lig. 15, I, 11, III, IV, and V). The tly ree elevitions, of which each gronp consists, form the angles of an isosceles trinngle the apex of which points away from the mouth of the larval (lig. 1.5). These elevations or eraginated papillir lie immediately below and inclose the tips of those branches of the radial water canals which form the rulliments of the end tentacle ant tirst pair of foot tentacles of each arm (tigs. 19 and 21). In this way each tentacle wrows into its ectorlerm, the latter closing aromen it as it pushes ont.

The function of these tentacles in the alult being manly a sensory one, it is interesting to mote that they receive their ectolerm from part of the same thickened oral area which gives rise liter to the adult nervons system.

The ciliaterl bands in "E" An not dille" in appearance and position from those in "D," but since they wer. not tigured in the earlier stage it may he well to refer to them again in connection with tigs. 15 and 16, ch, I, 2,3 , and 4. The tirst or most anterior band surromds the larval organ quite near its tip.

Near the first band, and parallel to it, rmos the second one also arome the larvil organ. The thind ciliated band is separated from the second by a much wider space than that which separates the tirst and second bands. Were it not intermuted on the oral disk the thibd eiliated hand would lie in the line separating the bivinm and trivium-that is, between arms 1 and If on the one sible and $I Y$ and $Y$ on the other. The fourth band, passing just posterior to the group of ertulermal chevations lying muler the branches of the flirul radial water tube, surronnds the posterior end of the larva. 
In ". l:" the cavities of the asophagus and stomach have become obliterater, and the two structures ajpear in section as one solid mass of cells (tig. 20, st and oe). No dergeneration in their size, lowever, is to be observed, and their onter walk remain well defined, the asophagus retaining its connection with the ectodern. As will bo secu later, their lumen reapuear and they' become tho definitive alimentary organs of the alult oplinuril.

leturning to the consileration of the watel" system, wo find in "l" insteal of one pair ot tentacles on cach radial manal, as in "l)," there are two pairs present (fig. 17, tl anul t2), the second pair having grown ont of the rachal canal between the first pair and the watel ring. The second pair is much smaller than those which were first to be formen, and, eontrary to what one wonll expect, this discrepancy in size loes not disappent as time goes on. This is also true in the sea-urchins, in which the primary tubo feet in the larva are enormously larger than thone which are subsequently formed. The primary tube feet in this case grandully diminish in sizo after the achut form is reacherl.

As a rule, among echinolems the tube feet or tentacles are formed centrifugally from the radial canals; that is, between the end tentacle and the last pair of tube feet or tentacles allearly formed. 'This process kceps the undiflerentiated growing point of each arm at its tip, lont in this ophinan, and the same is true of Anterlon, the formation of the tentacles begins in a centripetal manner; that is, the second pair of tentacles appears, not between the end tentacle and the first pair, but between the first pair and the ring canal.

This second pair of tentacles is the rndiment of the buesal tentacles, and althongh differing in both function and position in the alult from that of tho foot tenticles, is nevertheless entirely liomolngous with the latter. This homology is shown by their origin and the lact that for a time after forming they are lirected away from the month toward the end of the arm just as is the c:ise with the foot tentacles. After a time, however, as will be seen latel, they turn back and point towald the mouth, thus showing that in this second pair of ontgrowths from the ladial canals we have to do with the first pair of buecal tentacles of the adult. After bucling, as we see, from the radial canals, they migrate to a position on the ring eanal, with which we find then connected in the :ulult.

In "E" the buceal tentacles have no ectodrrm nor rudinent of such, the ectoclerm nuder their tips being as yet undifferentiated from the oral disk.

The hypogastric enterocule has assumed a more pentagonal shape than in "D," it having grown out over the radial water cumals (fig. 17, he). These projections of the hypogastric enteroecele will continne to grow with the growth of the arms aud become the brachial extensions of the body colom.

The interralial pouches of the hypogastric enterocule, which were beginning to form in "1)," lave jushed down further and further between the radial eanals until, coming in contalet with tho ventral ectoderm, they bend over, inserting thenselves between the ring canal and the oral disk (figs. 17-21, hip 1-2, 2-3,3-I, and $4-5)$. In tho same way tlie pouch from the interiur enterocule in the stone canal interradius has grown under the water ring. In these five interraclial enterocelie outgrowths, as has hecu mentioned hefore, we have the rmliments of the onter perihitual simus of the adnlt. The process by which this perihamal sinus is tormed in ophinra brevispina agrees in every detail with its method of origin in Asterina ! ibbose as describen by MeBnIDF (10).

The epigastrie enteroerale is in much the sume condition as that in which we left it in *.]), it being as yet too small to meet and form a mesentery with the dorsal edges of the hypogastrie eculom (tig. 19, ee).

The stone and pore canals, too, have changed very little during tho interval between "1)" and "E." From the ring canal at a point to the left of the origin of radial canal 1 the stone canal passes upwarl and opens into the right prostero-dossal part of the anterior enterocule. The prore canal begins at the same point where the stone canal ends, the two canals thus liaving a common

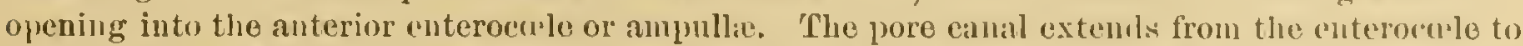
the dorsal surfico of the larva, where it empties through the dorsal pole at a point a lit tle to the right of the merlian sagittal plane. These two eanals, although extenling in the sane direction, do not lio in the same straight line, the pore canal being set a little anterior to and to the right of the stone canal (figs. 17, 1S, and 21, st and 1e; also lig. 11).

10396 $-3$ 


\author{
STAGE "F," 5 DAYS OLD.
}

(Figures 22-30.)

Although " $\mathrm{F}$ " is separated from the stage last described by a considerable space of time, the ehanges in the larva which have been bronght alsout are easy to follow.

The latra is considerably larger than in " $\mathrm{E}$," and has reachell its full development. From this time on the larval organ gradualls degenerates and is finally completely absorbed by the developing star (Compare figs. 2.2 and 31 lo.)

The external form of the larra has been elianged by the appearance of a number of elevations and depressions in its outer surface, the ciliated bands being elevated upon circular ridges (fig. 22 , cb $1,2, \therefore$, aud 4 ), while at points ou the sides of the disk beyond the end tentacles projections in the ectoderm have male their appearance, these being the rudiments of the ophiuran arms (fig. 22, I, II, IIl, IV, and V).

The larral organ is cylinirical, but the disk has continued its dorso-ventral flattening. (Compare figs. 22 and 26. .)

The first and second ciliated bauds are sitnated in the same places as in "E." The third, while retaining its old position, has grown in upon the rentral disk toward the month (itg. 22, cb 3). On the ventral sile of the larva the fourth band has shifted from its old position behind the third radial eanal to one on the interranlii between arms II and III and III and IV. It has also become interrupted on the oral disk in a manner similar to the third eiliated baud (fig. uㅗ, (cb t).

The depressions before referrell to are cansed by the invagination of the nervous system, rwhich structure has been forming since " $1 \mathrm{D}$ " in the thiekened orat disk of ectoderm. Immediately below the water ring and radial water canals the thickening has inereased more rapidly than at other points, thus producing a ring-shaped internal rilge, from which extend firo radial thickened ridges. These rudiments of the nerve ring and radial nerves bulge intardly, no evidence of their presence being apparent on the ontside. When the thickening process has been completel the whole nervous system gradually sinks in, leaving a circular groore from which five radial grooves pass out. This is the stage in the formation of the nerrous system which bas been reached in "F" (fig. 22, eg aud rg). The invagination process begins at the ends of the radial nerves, just inside of the curved tips of the ind tentacles, the nerve ring being invaginaten last of all. (Compare figs. 23-27.) As develupment goes on the edges of the grooves gradually close over the nerves, the closure taking place in the same order as the invagination proceeded-that is, first over the ends of the radial nerves, then finally, after gradually traveling up the radial nerves, closing over the nerve ring.

By the meeting and subseduent fusion of the edges of the groores, part of their cavity becomes cut off from the exterior and is left below the nervons system as the subneural space. But this will be referrel to again in an oller lanva, in which the process of its formation is more nearly completed, it having begun in a few only of the nost allvanced larvat of Stage "F."

The nervons system shows a differentiation into two distinct layers, a fibrons one nearest the water system and a ('ellular layer lying below the fibers (figs. 23-29). The nuclei of the cellular layer are oral, with their long diameter perpendienlar to the fibrons layer.

Above the nervons system, separating it from the water system, is to be fonul the onter peribilmal space (figs. $23-30$, olm). Recalling the comlition of the prerilicmal system in Stage " $\mathrm{E}$," we see that the ends of the interradial projections from the lypogastric and anterior enterocceles have grown out over the nervous system, spreading in both directions until the outgrowths of each interradial ponch meet those of its adjacent fellows in the radii over the origins of the radial nerves; liere the ents of the jouches fuse, and together they grow out over the radial nerves as the radial perihemal sinuses.

In the starfishes, where the formation of this perihemal system has been observer, it is said that no fusion takes place between the diverticnla of the interradial pouches of the hypogastric and anterior enteroceles when they meet in the radii, but that a mesentery is formed at the points where the diverticula come in contact. This mesentery is deseribed as continuing to the end of the arms, separating the radial spaces into two parallel eavities.

Nowhere could I find such a mesentery in sections of the larve of O. brevispinu, nor could I feel sure that it exists in the adult ophiuran. 
MCBRIYE (10) and GoTo (5) both agree that in startishes the inner perihiemal ring sinus arises from the anterior enteroenle, althongh they differ as to the methon of its formation. In none of the larva 1 have is the structure in efuestion fully formed, but in Stage " $\mathrm{F}$ " a cavity is arising, as an ontgrowth from the anterior enteroeule in the stone canal interralius, which I take to be the ruliment of the inner perihimal ring space. It lies to the left of the stone canal near the median sagittal plane of the larva. From the pusterior sille of the ventral end of the anterior chteroen le the ontgrowth takes its origin, then extending posteriorly until past the water ring it benls over and grows lown mutil its end reaches the nerve ring at a point insile the onter perihatmal sinns. Here the end of the ponch in ruestion hegins to spreal under the nerve ring in both directions, faraliel to the onter periladmal ring (figs. 24 and $26, \mathrm{ips}$ ). This coincides exinctly with its methol of origin in Asterinn giblosa as destribed by Mclinubs.

Althongh the onter perihilunal ring is entirely ent ofl' from the hody cuvities at this stage, there still remain traces of the interralial pouches which gave rise to it (tig. 29, lijp 1-2 and $4-7$ ).

The hypogastric enterocele itself has changed very little since Stage " 1 ," but the epigastric has enlirged to such an extent that its edges now meet the elges of the hypogastrie and a circular aboral mesentery is formed (figs. 23-29, cm).

In the water system considerable growth is to be noted in the tentacles, the eml and first pair of foot tentacles being capalle of protrusion consilterably heyont the disk. liy means of these tentates the larvit are able to eling tenacimsly to the surfaees of foreign bodies, it reyuiring a strong jet of water from a pipette to detach them. Special notice was taken to be sure that it was the tentacles and not the larval organ which was used as a means of attachuent.

The second pair of tentacles (bnceal tentacles) have acpurired their ertorlerm in this stage anul they protrude, like the other tentacles, over the radial nerves into the radial grooves (figs. 2.2 and $26, \mathrm{t} 2)$.

The axial simus or ampulla is present in "F," it being that part of the anterior "nterocxle which remains after the pouches have bedn ent off; which will form the inner preribamal and part of the outer perilh: mal systems (figs. 24,45, and 26 , ax sin).

It will be noted that besille the ampulla, which is simated anteriorly to the stone canal, there are two other eavities near the stone canal to be acconnted for (fig. 26 , sin a and sin b). I ean not he sure of their origin, but I believe that they also come from the anterior enterocrile. I have distinguisher them by the letter's a and b, as they are probably the same cavities as those so lettered by Mclikide (10) in his tigures of Ampliumal.

The cavity Mcbride has lettered $\mathrm{b}^{\prime}$, and which he thinks represents the degenerated right hydroccele, 1 have been mable to find in any of my sections.

The stomach and a'sophagus are in a condition the same as we found them in "li;" that is, without lumen.

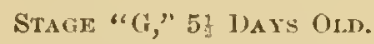

(Figures 31 and 32.)

Larvat a few hours older than "F" show a decided degeneration in the larval organ (fig. 31, lo), but otherwise the external appearance of the two stages is about the same.

The grooves caused by the invagination of the mervons system have bogun to disappear by the growing together of their elges, and insteal of the deep finrows we find a slightly depressed line where the elges of the grooves liave met (tig. : as, r.ge).

lu the nervous system a pair of tentarlo nerves has been formed from each radial nerve (fig. $31, \mathrm{nl})$. 'They grow out laterally from the radial nerves at points proximal to the first pair of foot tentaeles, aromol which latter they grow and to which they belong. No nerves as yet have appeared to supply the buckal tentacles.

In " $F$ " the bnecal tentacles land only begun to curve away from the end of the arm; but in "( $\dot{x} "$ this proxinal bending has continued until they curve over the nerve ring and point towarl the month.

Besile this chamge in the water vaseular system we find in "G" the first appearance of the rudiments of the polian resicles. They are four in number and ane in the form of small interra. dial pouches growing distally trom the eonvex wall of the water ring (ligs. 31 and $32, p v$ ). There is no polian vesicle present in this species in the stone canal interradius. 
As no perceptible change has taken place since " $F$ " in the organs not referred to above, the description of them given in the previous chapter will serve equally as well for " $G$ " as for " $F$," and the figures of these organs in "G" may be examined in connection with their cleseription in "F"."

$$
\text { Stage "H," } 8 \text { DAYS OLD. }
$$

(Figures 33 and 31.$)$

In the ollest larve I have, the metamorphosis has heen almost completel. The larval organ has nearly disappeared, that part of it which yet remains being fonnd stickiug to the elge of the aboral disk of the young pentagonal star.

When living the little ophiurids chung to the botton and sides of the aquaria dlishes. Although the ciliated bands were still evident on the disk their free swimming labits had been wholly given l].

The pore canal still opens on the aboral surface, but with the growth of the latter it is traveling toward the elge of the clisk, and by a continuation of this process the oral surface will ultimately be reached.

As the closure of the grooves over the nerrous system took place, circular areas below the tips of the tentacles were left open, the tentacle pores, and through these the tentacles, were able to protrude and withdraw themselves.

The smbneural sinnses which had begnn to be formed in "F" have been completed in the eight-lay larva (figs. 31 and 34 ss). In " $\mathrm{H}$," then, the nervons system is cushioned below by the subneural sinus and above by the outer perihamal riug.

The stomach, which for so long a period has been at a standstill in its development, has begun to grow, its sidles pushing ont between the epigastric and hypogastric body cavities. The lumen of both stomach and (esophagus have reappeared (fig. $34 \mathrm{~s}$ ). The glandular structure which makes the walls of the stomach so complicated in the adnlt has not hegun to form in " $\mathrm{H}$," the walls being simple and one eell in thickness.

No figure of " $\mathrm{H}$ " as a whole object has been made for the reason that the skeletal plates sboukl be included, and material adequate to a complete study of them is at present not in ny possession.

\section{RELATION OF LARVA TO ADULT.}

The hydrocole is the first organ to show radial symmetry in the developing larva of ophiurn brerispinu, and from the time when this organ has completed its rotation abont the orsoplagus it show's a refinite relation to the plane of bilateral symmetry of the larva.

The hydrocole is not only radially symmetrical, but bilaterally symmetrical, since it is rliviled into symmetrical halves by the plane which passes throughl radial eanal 3 and through the iutermalins of the stone canal. This plane coincides with the plane of bilatelal symmetry of the larva. The other parts of the star are built abont the water rascular system; hence it, as a whole, bears a. similar lelation to the larva as was initiated by the hydrocole.

No secondary twisting of the varions prarts of the star ocenrs, and its relation to the larva remains constant as it began, and thronghont the life history of the species tho following statements hold true: Ventral and dorsal in the larval are erpiralent to oral and aboral in the ardult. Althongh no physiologieal differentiation exists, if wo regarl that part of the adult as anterior which was anteriorly directed in the free swimming lava, the trivinn is anterior, the bivium is posterior.

In the foregoing I bave confirmed, in an ophinril, the conchnsions drawn by (iomo from lis studies on a starfish. In his work on the development of Asterins pallida Goto (5) thought he was able to prove the coincidlence of hilateral symuetry, which obtains in the adult starfish, with the plane of bilateral symmetry of the bipinuarian and hachiolarian larvil.

The stuly of the relation of larva to adult in the starfislies is male most diflicult, lowerer, by the independeut origin and sulserequent twisting of the parts of the star. At the time of their origin no two parts of the star bear the same relation to the larva. The relation of each part to the larva also changes as metamorphosis pioceds.

The facts just enumerated admit of other conclusions than those deduced by Goro, and no 
two investigators have reached the same conchision. The point of view from which the subjeet luas been approached is not the same in all cases, but the results obtained by those who have studied the question admit of being redueed to the same basis; that is, the relation of the planes of bilateral symmetry in larva and adult.

Cukinot (4) in his latest work denjes the existence of any known relation between them.

Swuon (13), working on a holothmian, fomd the two planes in question to concide, but his eonchision is basen on the supposition that the dorsal mesentery of the adult is the sime as that of the anricularia larva, which smposition liver has since shown to be inforrect.

Bver (3), after working on members of all the groups of echinoderus, coneluded that the plane of bilateral symustry of the larval form coineides not with the plane dividing the adnt form into two symmetrinal halves, but with the plane of radial symmetry.

HCBniDE's(10) observation on a startish, Asterina gibbosa, led him to aropt abont the same view as that of BuRr. He found that the plane of ladial symmetry of the star makes an angle of 700 phis with the fiontal plane of the larva, but way, withont error, be considered as 90 . This is eynivalent to saying that the plane of radial symmetry of the star is parallel with the sagittal plane or the plane of bilateral symmetry of the larva, and is also reducible to the statement that the planes of lijatelal symmetry of the linva and adult are at right angles to one another. Thus right and left in the larva become aboral and oral in the adult.

The rifierence in results arrived at by Goto and MCBRide are due almost wholly to the stages in the metamorphosis selected in each ease for the stury of the cluestion, Goto selecting a very lite stage, when the larvil buly had all but disalpeared, while the stage chosen by McBRIDE is an early one, in which the rudinents of the star are just appearing.

If the five groups of echiuoderms have sprumg from a common stem after radial symmetry had been established, then in the metumorphosis which is found in all the gromps there should he discoverable a unity of relation between larva and adult. It is hard to conceive uf the radial symmetry of echinoderms as having been independently acyuired by each group, althongh it is easy to seo how secondary changes may have arisen in the metamorphosis since the grom separated.

The tive gronps of echinoderms stand isolated from one another almost as completely as does the echinoderm bluylum from the other phyla of the animal kingdon, and it is not my intention at this time to enter into a discussion of the interrelationships of echinoderms. I wish, however, to point out an interesting series of faets fresented by nembers of the Asterid, Crinoid, and $O_{p}$ hinrid groups which may have a bearing upon the subject, and in the same connection I wish to call attention to how well McBride's hypothetical ancestor of the Asterids and Crinoils (10, fig. -), when letails are not too closely compared, fits into the ficts of the lavia of Ophinera brevispina.

In one of the Astericls Goto his shown that toward the end of metamorphosis the almost complete star sits as a cap at the posterior end of the larva, with its aboral end posterior, its oral surface anterior, the bivium dorsal, and the trivium ventral.

In Autedon, like the starfish, the rotation brings the developing crinoid head to the posterior end of the larva, but diflering dianetricaly from the starfish in that the olal instean of the aboral surfice of the crinoid is posterior; but this dillerence does not in any way atlect the homologies between the trio groups as lias been supposed.

In Ophiura brerispinn the relation of larva and adult at the time of metamorphosis is approx. imately the same as is shown in Stage " $F "$ (fig. 2.$)$, in which ventral in the larva is ventral (oral) in the adult.

Now, if we take an ophimran larva at Stage "F," and imagine the disk to rotate in sneh a way as to bring its oral surface away from the larval organ or preoral lobe, it fairly represents that which takes place in the metamorphosis of $\Delta$ ntemon, bnt if we think of it as rotating in the opposite way, bringing the aboral surtice away from the prearal lobe, then it more nearly illustrates the starlish metamorphosis.

In Antedon, as metamorphosis proceeds. the stem is carried on to the aboral surfice, while in the startisl the preoral lobe finally disappears on the oral surface. In O. brevispina the place of disajperuance of the larval organ more nearly recalls the rimoid than any other erhimulerm, the larval organ being found in some of my oldest specinens as a small binob ucar the edgo of the aboral surface between arms 1 and $V$. 


\section{COMPARISON OF THE LARVA OF ANTEDON ROSACEA WITH THAT OF OPHIURA BREVISPINA.}

While I was studying the larva of Ophiura brevispina, eharacters were constantly being found which reminded me of the larvin of Antedou as described by licliz (1). Some of these points of resemblanee are no lonbt only superficial, but others are such as to make it worth the while to devote a short eliapter to the similarities of the two larvale

The entire ciliation of the very young larvit gives place in both to a series of transverse ciliated bands, five in Autedon, four in Oplnura. The band nearest the anterior end of the Antedon larva, however, is suall and inconplete. 'Two bands ouly in each case snrronnd that part of the larva from whieh the disk is formed.

The blastopore in both larvie, after shifting from a posterior position to one on the ventral surfice, closes and the arehenteron loses its comnetion with the ectoderm and lies free in the hody eavity.

In the seven-day embryo of Antedon and Stage " $\mathrm{C}$ " of Ophinura the hydrocrele is a horseshoeshaped structure lying in the posterior ventral part of the larvat with the open ent directed anteriorly, and in each case the plane of ralial symmetry of the liydroccele is at right angles to the plane of bilateral symmetry of the larvir.

In the formation of the paired tentacles from the radial water canals the process is begun centripetally in both larvid, the second pair of tentacles appearing between the first pair and the water ring instead of between the first pair and the end tentacle, as is the ease in the other groups of echinoder'ms.

In the tive-day Antedon larra and those stages represented by "D" to "F" in Oplinu"a the stalk and larval organ are strikingly similar, both in shipe and pesition, the two structures being anteriorly direeted in swimming.

The stem of the Antedon larra, as a result of metamorphosis, eomes to be an aboral structure, and just betore the disappearance of the larval organ from the ophinum larva it is to be found as a small knob, not in the center of the aborial disk, it is true, but on its edige. In the starfishes it may be reealled that the prenral lobe disippears on the orul surface of the metamorphosing star.

To the alove larval characteristies may be alded the similarity whieh exists in the disposition of the alimentary and exlomic systems in the adult forms.

In both Crinoids and Ophiurans the digestive apparitus is confinei to the disk.

The body cavity is continned into and to the ends of the arms. When a transverse section of a pinumle of Antedon is compared with a transverse section of an ophinid arm, the following striking correspondence is found in the parts: Aborally, segmentally arrangerl calcarions ossicles and muscles are present; a continnation of the body celom runs between and oral to the muscles; connected with and on each side of this central brachial body cavity are two other cavities, the subtentacular (anals of Antedon. These latter in the Ophiuraus are connected with perihiemat space in each vertelural segment.

The radlial water tube lies between the subtentaenlar eanals, and in each segment sends out a pair of tentacles. The tentaces in both the Crinoids and Opliturids are hevoid of the terminal suckers, which are so char"ueteristic of the other echinodems.

Separating the radial water tube from the nerve eord is to be found the radial perilitmal sinus.

In ophinrans a subneural space is present which is not represented in the crinoid arm. This is due to the fact that in Antedon the nervous system is superfieial, while in Ophiura it has been invaginated, aud with its iuvagination a spate has also been carried in below it.

\section{LITERATURL CITED.}

1. BURY, JI. "Early Stagrs in tho Development of Anterlon rosacen." Philosophical Transactions, vol. 170. 18k8.

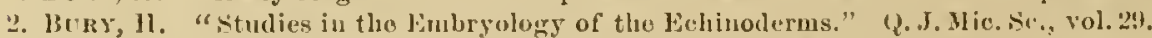

3. Litus, I1. "The Metamorphosis of lichinoderus." Q.J. Mic. Su., vol. 3K.

I. Cuwor, L. "Etules Marphologinnes sur les Echinolemes." Archiv. Biol. t. XI.

5. (ioto, S. "The Metamorphosis of Asterias pallidit, with special refernne to the fate of the liody Cavities." Journal of the Collegre of Scione lmp. Iniv 'Tokyo, dapan. Vol. X, l’t. IIt. I8!s.

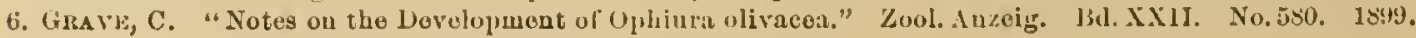


7. Krous, A. "Ueber oineu nenen Entwickelun rsmodus der Ophimen." Muelher's Archiv. f. Anat. n. Phys., 18.5i, 1.369.

8. LrMas, T. "Ophiura brevispinil Say." Pt. I. 111. Cat. Mns. Comp. Zool, Larvaril Coll. 1865, p. 16.

9. Lrmax, T. "Report on the (Iphinridir." Vol. V. Challouger lieport.

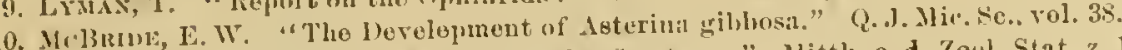

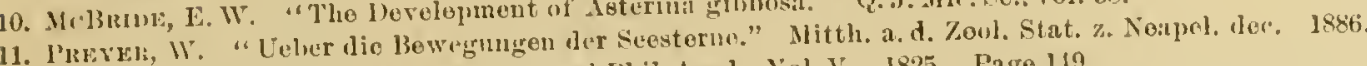

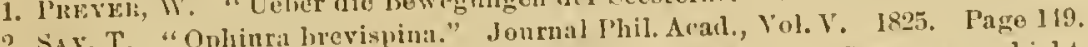

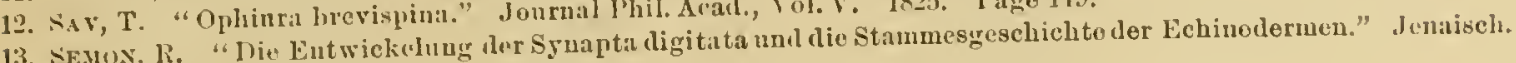

13. SFunx, R. "Dite Litwick(hutg dons

\section{EATIANATION OF PLATES.}

The figures illnstrating this paper wore drawn to the same seale of mirnification, 330 dliameters, and were reduced one-halt in reproduetion.

Fins. $1,2,4,6,7,9,17,31$, and 32 were reconstrueted from series of trausverne ind sagittal sections.

In all cases larra.

ABMBEVIATIONS USED

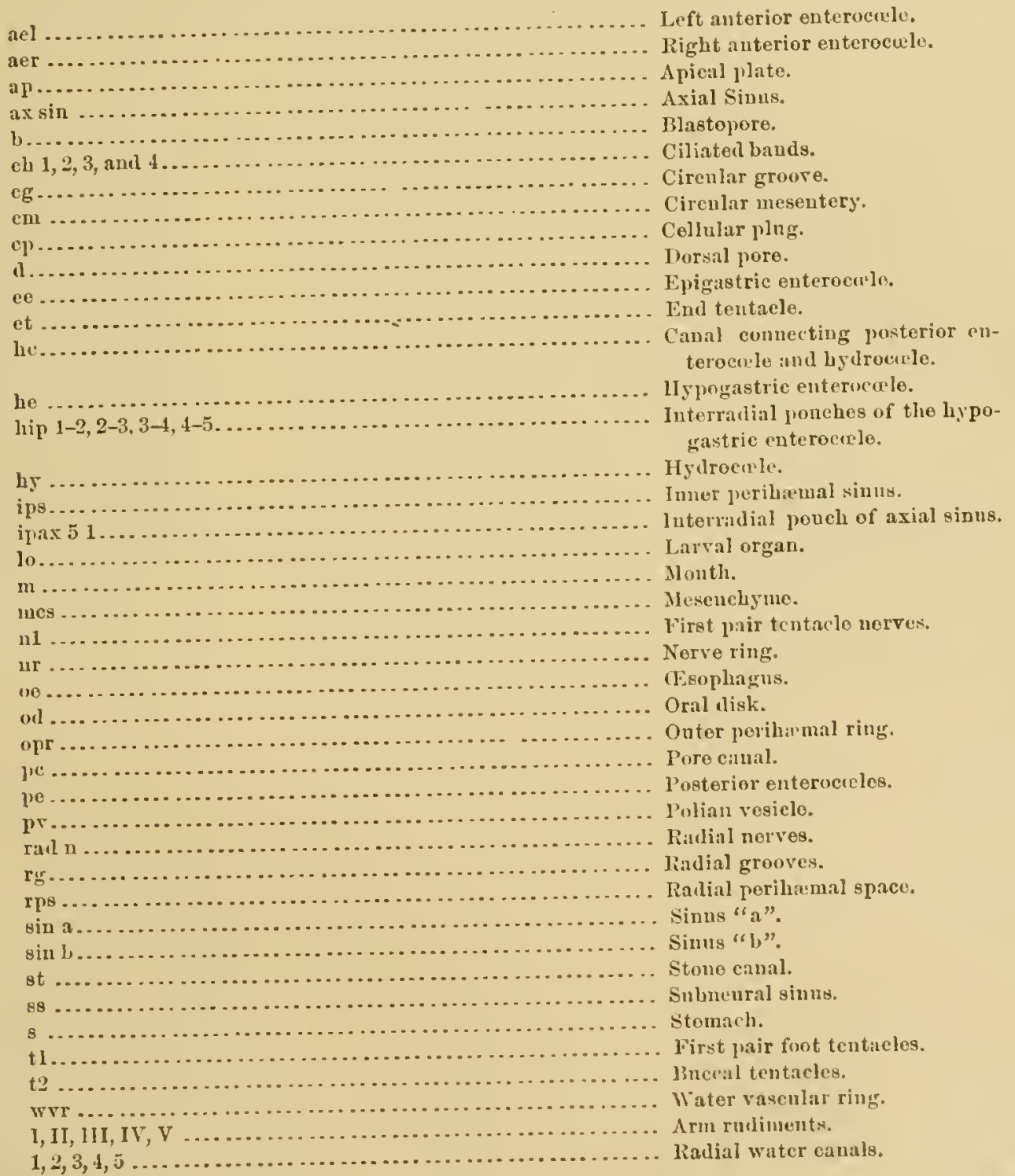




\section{Plate I.}

Fig. 1. Larva in Stage " $\Lambda$," keen from the right side, the riglt half of the eetoderm remored and tho anesenchyme omitted.

Fig. 2. The same larva, secn from the veutral side as a transparent object.

Fig. 3. Meulian lougitudinal soction of a larva in stage " $A . "$

Fic. A. A larra in Stage "B," viowerl from the ventral side as a trunsparent object.

Fig. 5. Transverse section of a larva in stage " $B$ " in a pline halfway let ween the lulastopore aud the point where the hydrocele is connected with the anchenteron.

Fig. 6. Larra in Stage "C," seen from the rentral sicle, the ventral half of the ectoderm, tho mesenehyme, aud part of the asophagus renoved.

Fig. 7. The litt lialf of the same larva.

lik. 8. Transverse scetion throngh Stage " $\mathrm{C}$ " in a plano inclicated on fig. 6 by the letters $a-b$.

Fig. 9. The reconstructer internal anatomy of a larva in Stage "D," the ventral ectodern removcd and with it jart of the cesophagns.

Fig. 10. An ontlino drawing of fig. 9, on which are indicated by lines the planes of the sections which follow in figures $11,12,13$, and 11 .

Fig. 11. Longitudinal scction taken throngle a larva in stage "I)" in the plano indieated on lig. $10 \mathrm{by}$ the lino $m-n$.

FIGs. 12, 13, and fig. 14 of Plate $1 \mathrm{I}$. 'Jrausverse sections taken thruugh Stage " $\mathrm{D}$ " in planes inclicated on tig. 10 by tho lines $a-b, c-d$, and $e-f$.

Plate II.

FIG. 15. Ventral view of a larva in Stage "E," to show ciliated bands aud first appearance of the arm rudimcuts.

Fic. 16. Jorsal riew of Stage "k," showing the eiliatel hands.

F1G. 17. A reconstruction of the anatomy of a larra in stage "L," the rentral ectoderm removed.

FIg. 18. An ontline drawing of fig. 17, on which are indicated by lines the planes of the sections shown in figs. 19 , 20 , and 21.

Figs. 19, 20, and 21. Transporso scctions taken through larra in stago "E" in plancs indicated on fig. 18 by the lines $r-8, t-u$, and $v-u$.

FIG. 31. lieconstrnction of the anatomy of a larva in Stage "G." In this cabe as in all tho other reconstrnctions the ventral surfice is up and the ventral ertodern romover.

FIG. 32. An ontline alrawing of the water vascular syotem of al larva in stage "G", seen from the ventral surface.

lig. 33. Transverse section of Stage " $H$," taken through the region of the stone canal.

FIG. 34. Transverse section of a larva in Stage "H," taken through the stomach.

\section{FIATE ]11.}

FIG. 22. Ventral view of the fully developed larva hefore untamerphosis has begun. Stage "F."

Fig. 23. Ontline drawing of fir. 22. The lines indicate the planes of the sentious, which have becn drawn to show the anatomy of a larva in Stage " $l$ "."

FIGs. 24, 25, 26, and 27 . Longitudiual sertions of a larva in stage " $\mathrm{f}$ " " tho planes of which are indicater on fig. 23 hy the lines $a-b, c-d, m-n$, and $x-y$.

Figs. 28, 29, and 30. Transverse soctions of a larva in Stage " 1 ", the planes of which are indicated on fig. 23 by tho lines $c-\theta, d-o$ and $c-0$. 


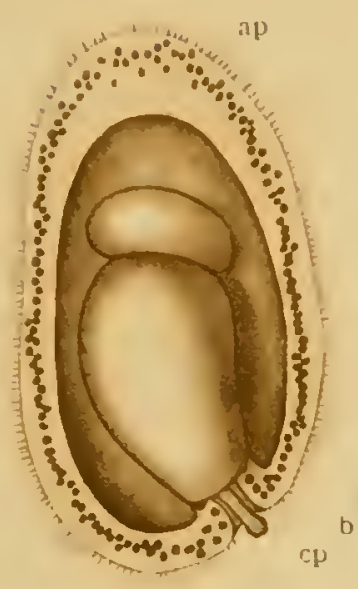

Fig. 1.

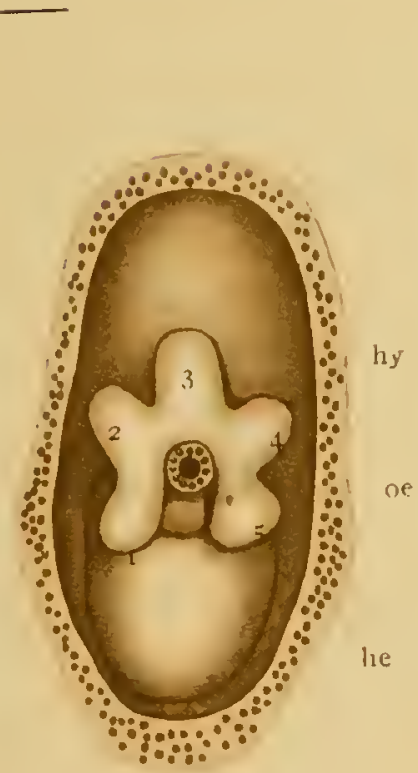

Fig. 6.

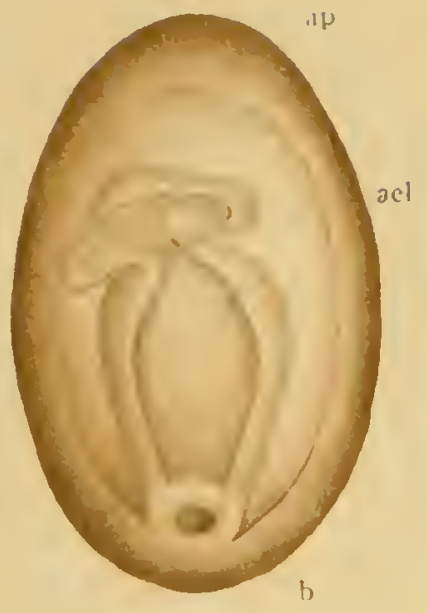

Fig. 2 .

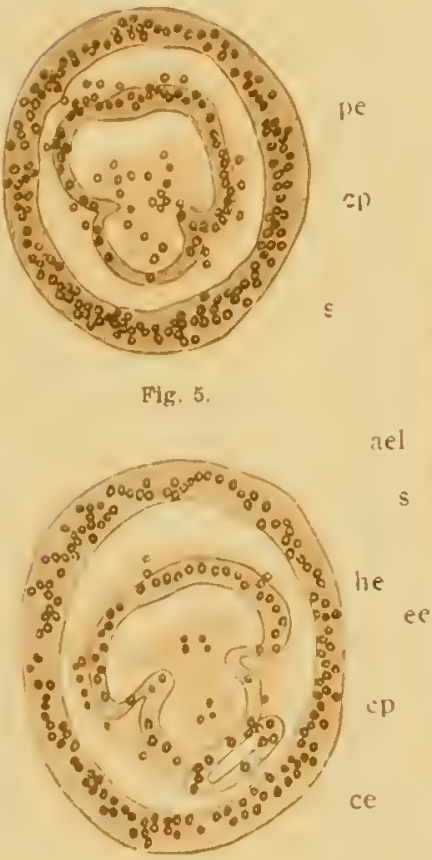

Fig. ${ }^{4}$

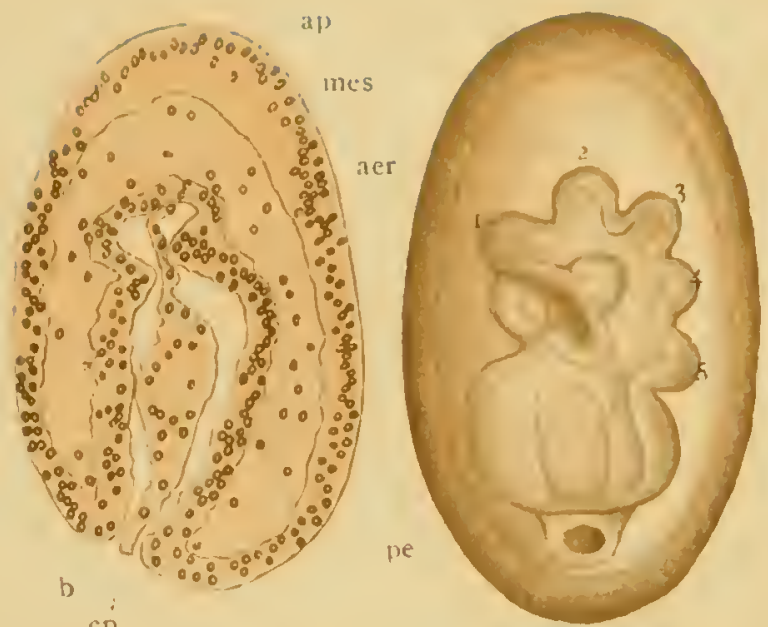

l,
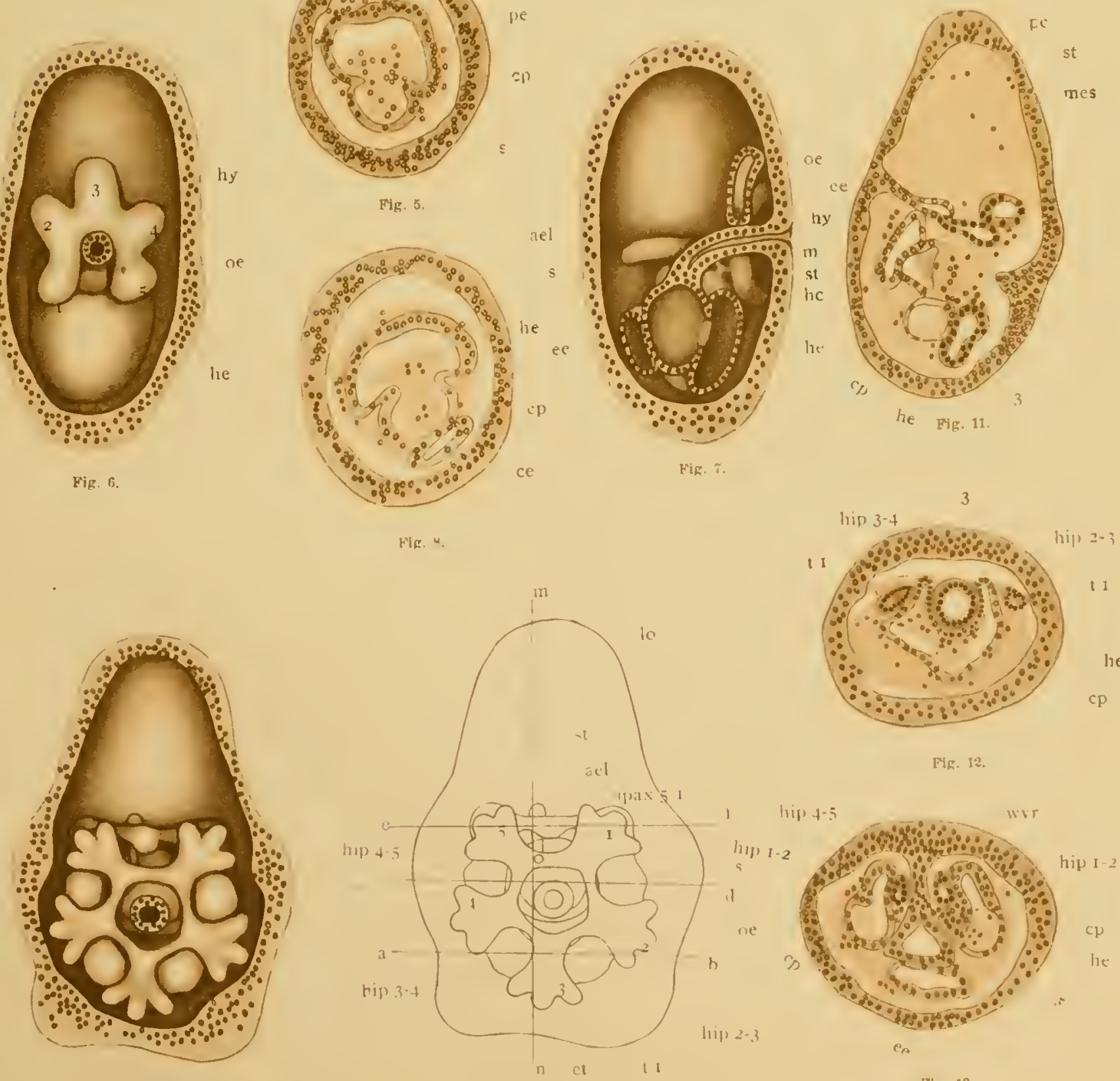

Fig. 12.

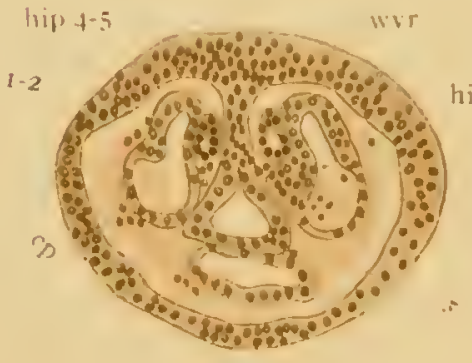

Fig. 10.

Fig. 13 



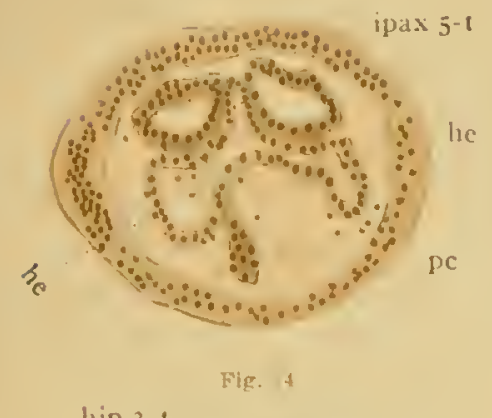

hip 3-4 12 hip $2-3$

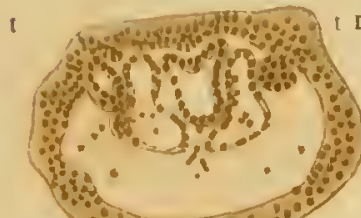

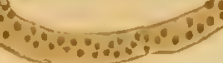

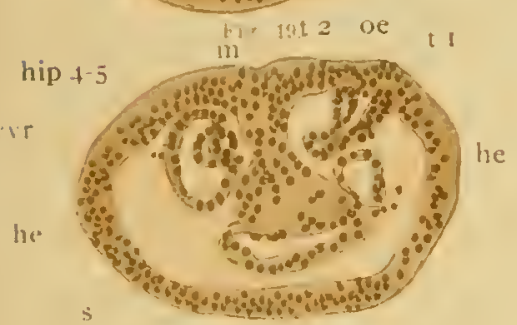

ee

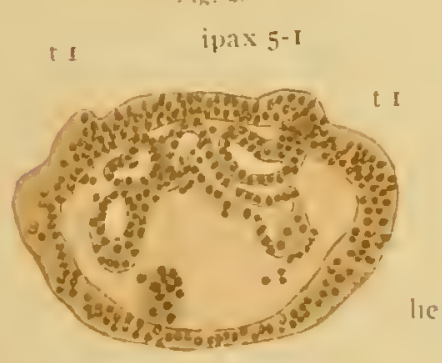

lo

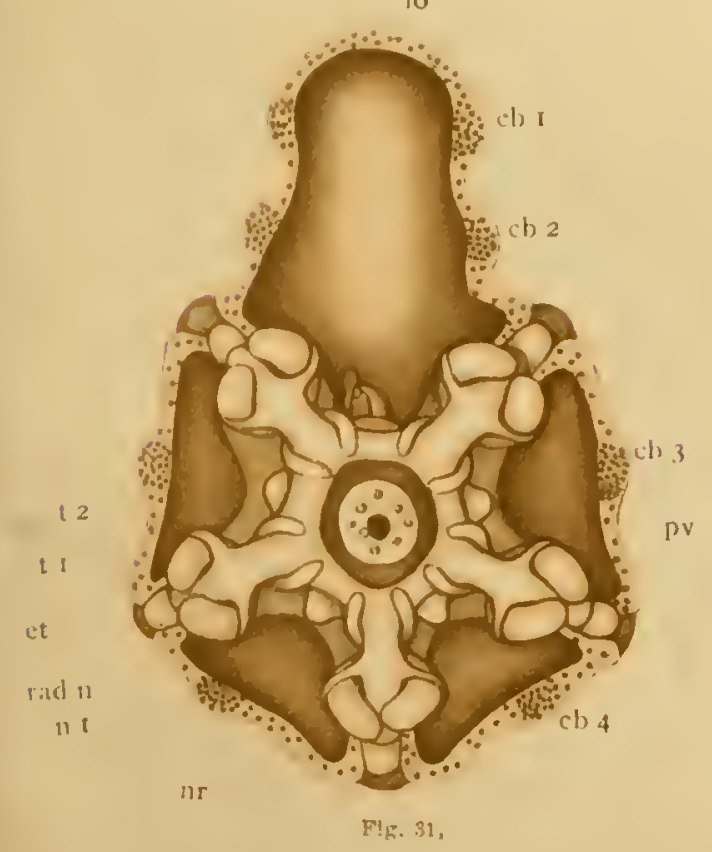

hip 4-5
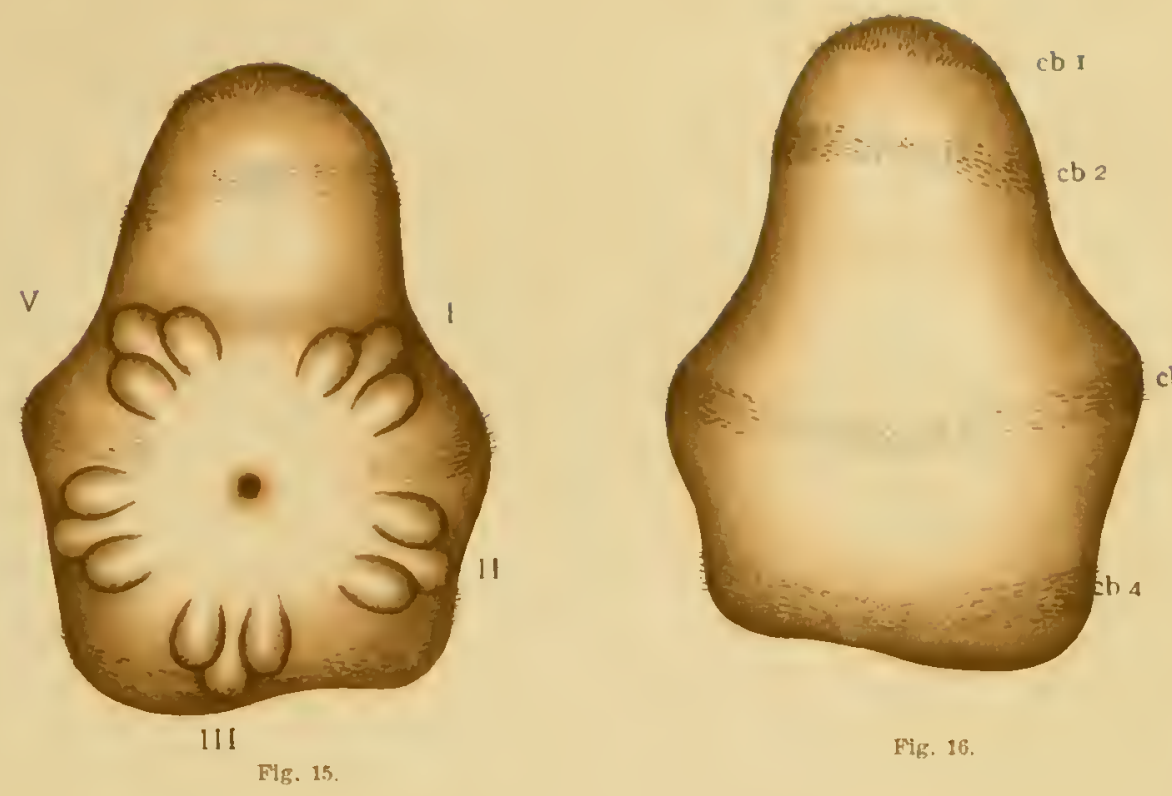

Fig. 16.
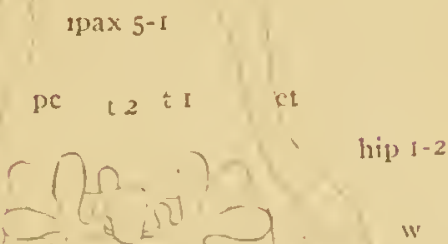

he

lup 3-4

(i) b

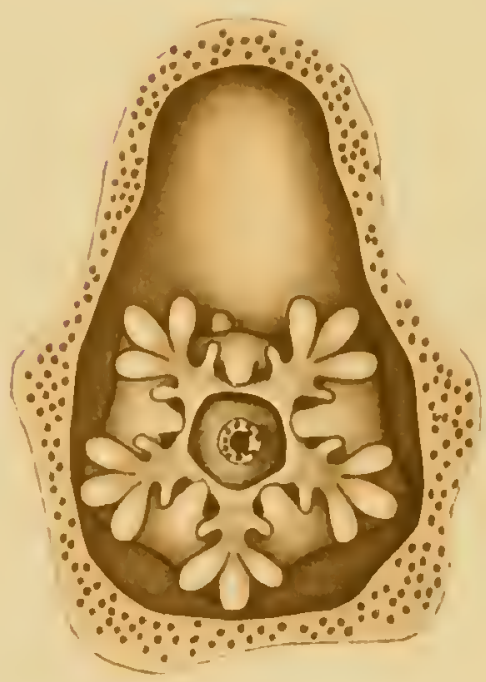

Fig. 17.
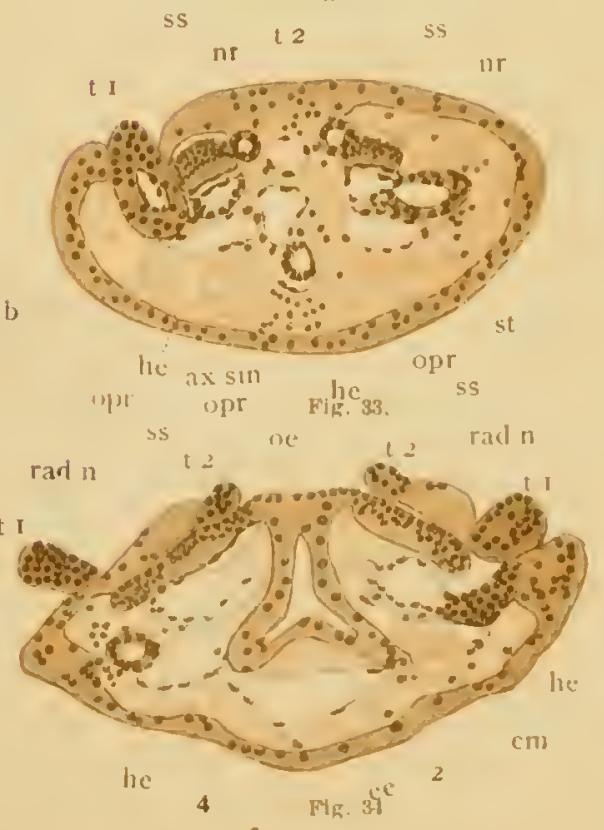


$$
\text { - }
$$




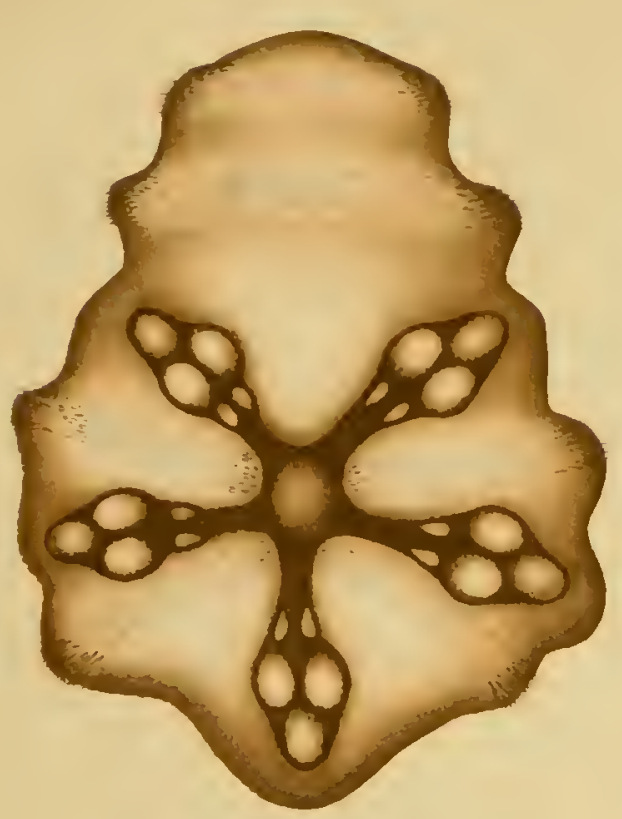

Fig. 22.

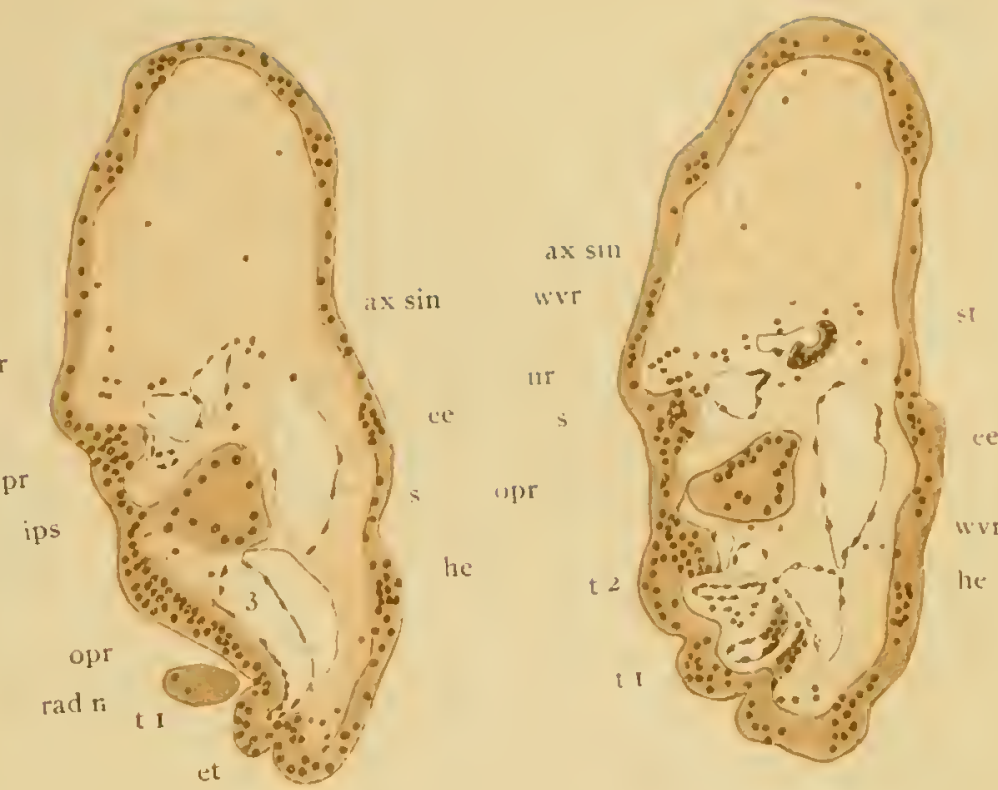

Fig. 24.

FIg. 25.
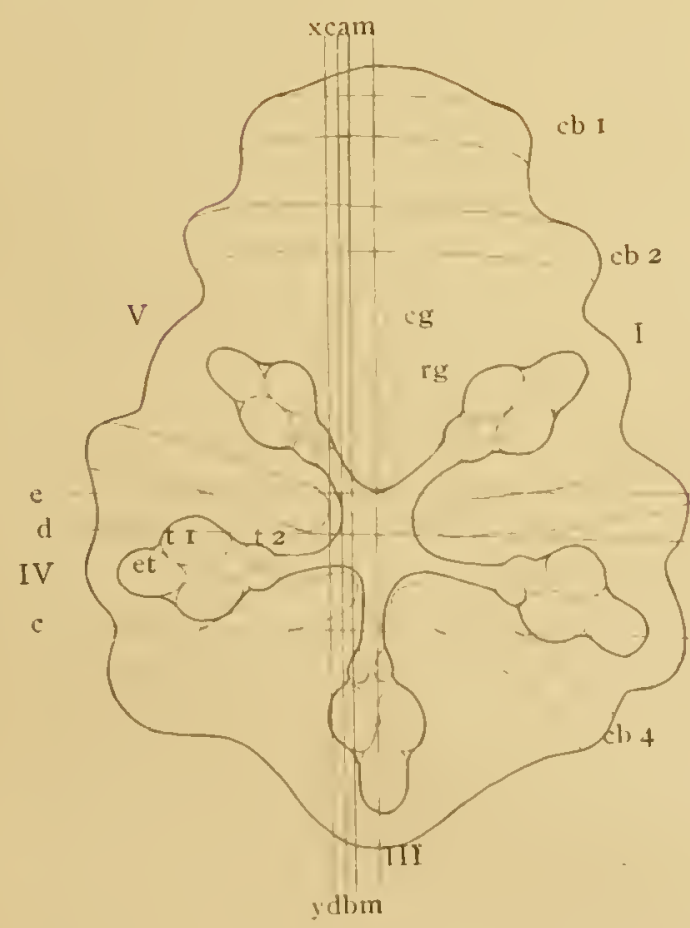

Fig. 23.

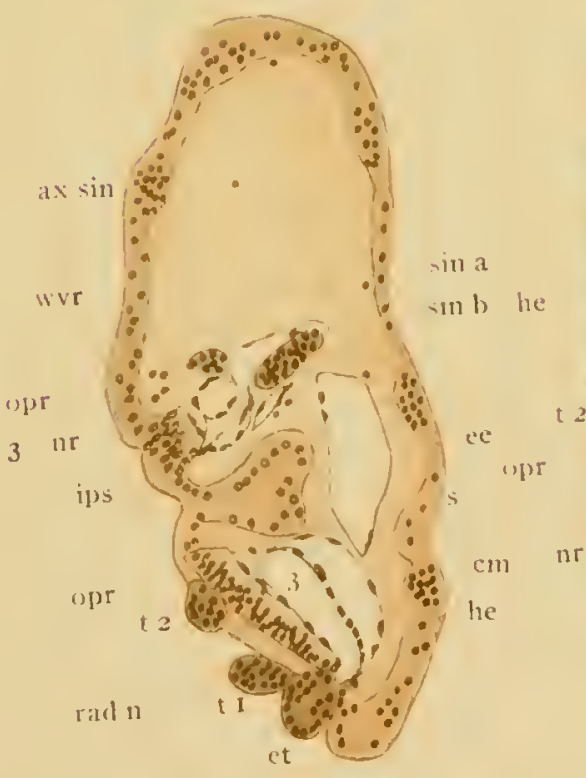

Fig. 26.

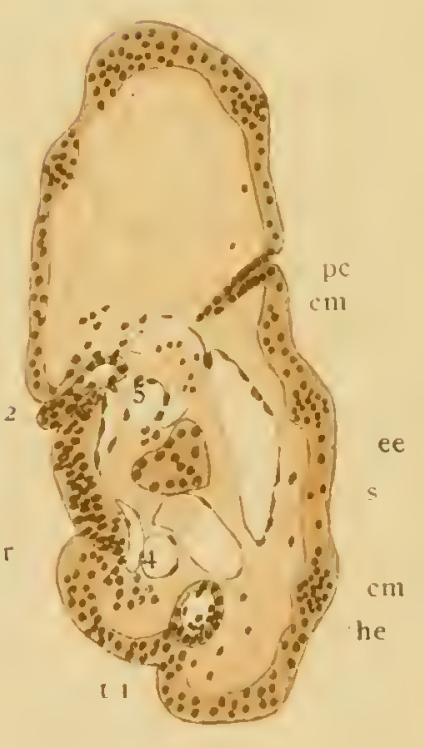

Fis. 2 .

nr

ipr

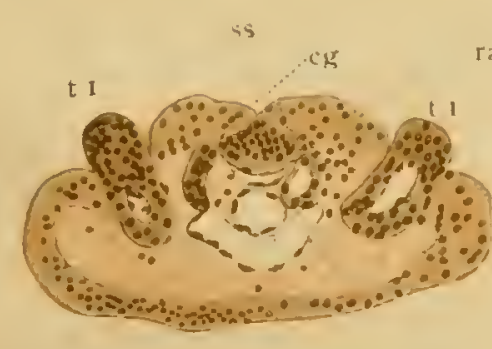

rps

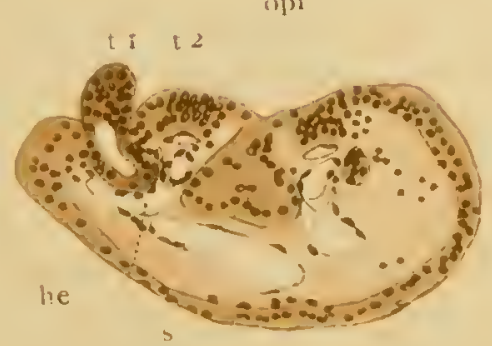

(in his 1=?

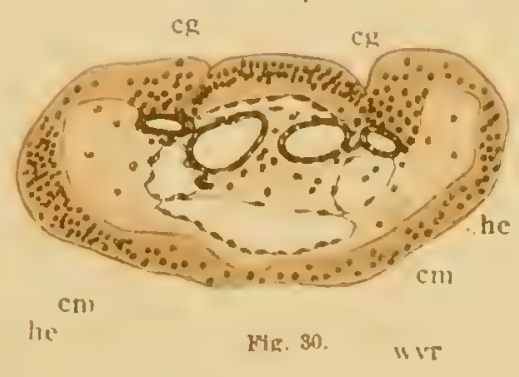






